\title{
Primary and secondary transcriptional effects in the developing human Down syndrome brain and heart Rong Mao ${ }^{* \dagger}$, Xiaowen Wang, Edward L Spitznagel Jr§, Laurence P Frelin`, Jason C Tingף, Huashi Ding ${ }^{\ddagger}$, Jung-whan Kim ${ }^{\ddagger}$ Ingo Ruczinski, Thomas J Downey ${ }^{\ddagger}$ and Jonathan Pevsner ${ }^{*+q}$
}

\begin{abstract}
Addresses: *Program in Biochemistry, Cellular and Molecular Biology, Johns Hopkins School of Medicine, 1830 East Monument Street, Baltimore, MD 21205, USA. 'Department of Neuroscience, Johns Hopkins School of Medicine, 725 North Wolfe Street, Baltimore, MD 21205, USA. ${ }^{*}$ Partek Incorporated, St Charles, MO 63304, USA. §Department of Mathematics, Campus Box 1146, Washington University, St Louis, MO 63130, USA. "Department of Neurology, Kennedy Krieger Institute, 707 North Broadway, Baltimore, MD 21205, USA. ${ }^{¥}$ Pathobiology Graduate Program, Johns Hopkins School of Medicine, 720 Rutland Avenue, Baltimore, MD 21205, USA. \#Department of Biostatistics, Johns Hopkins Bloomberg School of Public Health, 615 North Wolfe Street, Baltimore, MD 21205, USA.
\end{abstract}

Correspondence: Jonathan Pevsner. E-mail: pevsner@kennedykrieger.org

Published: 16 December 2005

Genome Biology 2005, 6:RI07 (doi:10.1 186/gb-2005-6-13-r107)

The electronic version of this article is the complete one and can be found online at http://genomebiology.com/2005/6/I3/R/07
Received: 26 July 2005

Revised: 4 October 2005

Accepted: 2I November 2005

(c) 2005 Mao et al.; licensee BioMed Central Ltd.

This is an open access article distributed under the terms of the Creative Commons Attribution License (http://creativecommons.org/licenses/by/2.0), which permits unrestricted use, distribution, and reproduction in any medium, provided the original work is properly cited.

\begin{abstract}
Background: Down syndrome, caused by trisomic chromosome $2 \mathrm{I}$, is the leading genetic cause of mental retardation. Recent studies demonstrated that dosage-dependent increases in chromosome $2 \mathrm{I}$ gene expression occur in trisomy $2 \mathrm{I}$. However, it is unclear whether the entire transcriptome is disrupted, or whether there is a more restricted increase in the expression of those genes assigned to chromosome $2 \mathrm{I}$. Also, the statistical significance of differentially expressed genes in human Down syndrome tissues has not been reported.
\end{abstract}

Results: We measured levels of transcripts in human fetal cerebellum and heart tissues using DNA microarrays and demonstrated a dosage-dependent increase in transcription across different tissue/cell types as a result of trisomy 21 . Moreover, by having a larger sample size, combining the data from four different tissue and cell types, and using an ANOVA approach, we identified individual genes with significantly altered expression in trisomy $2 \mathrm{I}$, some of which showed this dysregulation in a tissue-specific manner. We validated our microarray data by over 5,600 quantitative real-time PCRs on 28 genes assigned to chromosome $2 \mathrm{I}$ and other chromosomes. Gene expression values from chromosome 2I, but not from other chromosomes, accurately classified trisomy $2 \mathrm{I}$ from euploid samples. Our data also indicated functional groups that might be perturbed in trisomy 21.

Conclusions: In Down syndrome, there is a primary transcriptional effect of disruption of chromosome 21 gene expression, without a pervasive secondary effect on the remaining transcriptome. The identification of dysregulated genes and pathways suggests molecular changes that may underlie the Down syndrome phenotypes. 


\section{Background}

Human autosomal abnormality is the leading cause of early pregnancy loss, neonatal death, and multiple congenital malformations [1,2]. Among all the autosomal aneuploidies, Down syndrome (DS), with an incidence of 1 in approximately 800 live births, is most frequently compatible with postnatal survival. It is characterized by mental retardation, hypotonia, short stature, and several dozen other anomalies [3-5].

It has been known since 1959 that DS is caused by the triplication of a G group chromosome, now known to be human chromosome $21[6,7]$. As for all aneuploidies, the phenotype of DS is thought to result from the dosage imbalance of multiple genes. By the 1980 s, a primary effect of increased gene products, proportional to gene dosage, was established for dozens of enzymes in studies of various aneuploidies [5]. More recently, microarrays and other high-throughput technologies have allowed the measurement of steady-state RNA levels for thousands of transcripts in human DS cells [8-10] and in tissues obtained from mouse models of DS [11-15]. Most of these studies have confirmed a primary gene dosage effect. We previously measured RNA transcript levels in fetal trisomic and euploid cerebrum samples, and in astrocyte cell lines derived from cerebrum [16]. We observed a dramatic, statistically significant increase in the expression of trisomic genes assigned to chromosome 21.

The secondary, downstream consequences of aneuploidy are complex. A major unanswered question is the extent to which secondary changes occur in DS as a consequence of the aneuploid state. On chromosome 21, gene expression may be regulated by dosage compensation or other mechanisms such that only a subset of those genes is expressed at the expected $50 \%$ increased levels. For genes assigned to chromosomes other than 21, the effect of trisomy 21 (TS21) could be relatively subtle or massively disruptive. It has been hypothesized that gene expression changes in chromosome 21 are likely to affect the expression of genes on other chromosomes through the modulation of transcription factors, chromatin remodeling proteins, or related molecules $[5,17,18]$. Recent studies in human and in mouse provide conflicting evidence, with some studies suggesting only limited effects of trisomy on the expression of disomic genes, whereas other studies indicate pervasive effects (see Discussion).

In the present study, we assessed five specific hypotheses relating to primary and secondary transcriptional changes in DS. First, which, if any, chromosomes exhibited overall differential expression between TS21 and controls? Our previous study in human tissue $[8,16]$ suggested the occurrence of dosage-dependent transcription for chromosome 21 genes, but not for genes assigned to other chromosomes. The present report addressed whether this phenomenon applies to multiple tissues in DS.
Second, which, if any, genes assigned to chromosome 21 exhibited differential expression between TS21 and controls? Third, which, if any, genes on chromosomes other than chromosome 21 exhibited differential expression between TS21 and controls? Previous studies by other groups $[8,9,19,20]$ and by us [16] lacked sufficient statistical power to identify significantly regulated genes in DS. The present study identified such genes by using a larger sample size, by combining previous data from cerebrum and astrocytes [16] with gene expression data from additional tissue types (cerebellum and heart), and by using analysis of variance (ANOVA).

Fourth, can we classify tissue samples as TS21 or controls using genes on chromosome 21 or genes on chromosomes other than 21? Classification is a supervised learning technique that provides a powerful statistical approach to address the question whether only chromosome 21 or the entire transcriptome is involved in DS. Fifth, which, if any, functional groups of genes exhibited overall differential expression between TS21 and controls? Such analysis may reveal biological processes that are perturbed in DS.

In this study we measured gene expression in heart and cerebellum, two regions that are pathologically affected in DS. Total brain volume is consistently reduced in DS, with a disproportionately greater reduction in the cerebellum [21,22]. Furthermore, a significant reduction in granule cell density in the DS cerebellum has been reported for both human and the Ts65Dn mouse model of DS [23]. Another prominent phenotype of DS is congenital heart defects. TS21 has the highest association with major heart abnormalities among all chromosomal defects, and $40 \%$ to $50 \%$ of $\mathrm{TS} 21$ children have heart defects $[24,25]$. Of those children with heart abnormalities, $44 \%$ to $48 \%$ are specifically affected with atrial ventricular septal defects (AVSDs) [26]. Other commonly affected tissues in the DS heart include the valve regions, such as pulmonary and mitral valves [27,28]. Barlow et al. [29] assessed congenital heart disease in DS patients with partial duplications of chromosome 21, and established a critical region of over 50 genes. The expression levels of these genes in fetal TS21 heart samples have not yet been assessed.

Our data showed consistent, statistically significant overall dosage-dependent expression of genes assigned to chromosome 21. Analysis of these data identified genes with most consistent dysregulation of expression in different TS21 fetal tissue and cell types, most of which were independently confirmed by quantitative real-time PCR. We successfully classified tissue samples using expression data from chromosome 21 genes, but not with the data on non-chromosome 21 genes. Statistical analyses on our microarray data also indicated tissue-specific, regulated functional groups of genes, which may provide initial clues to perturbed biological pathways in TS21. Overall, the data support a model in which the aneuploid state increases the expression of chromosome 21 genes, with 
(a)

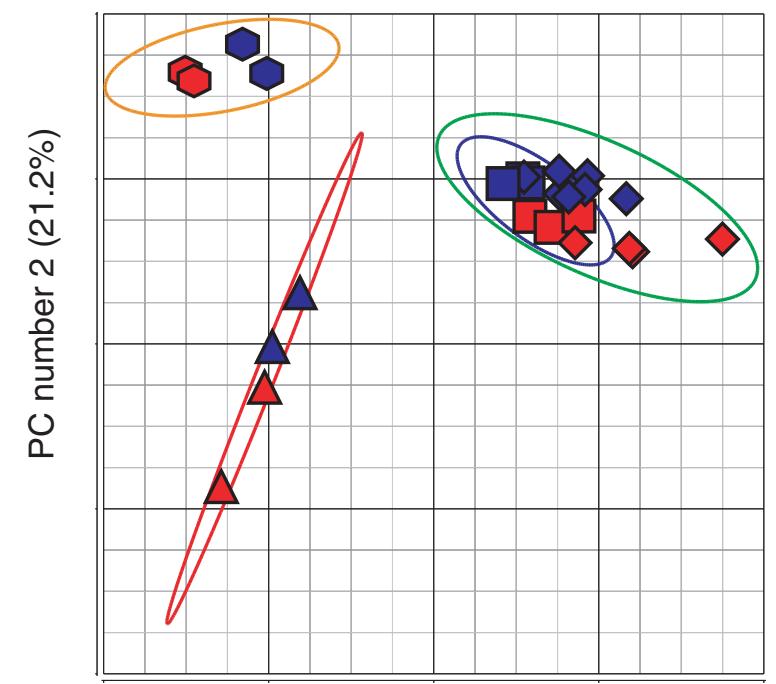

PC number $1(41 \%)$

(c)

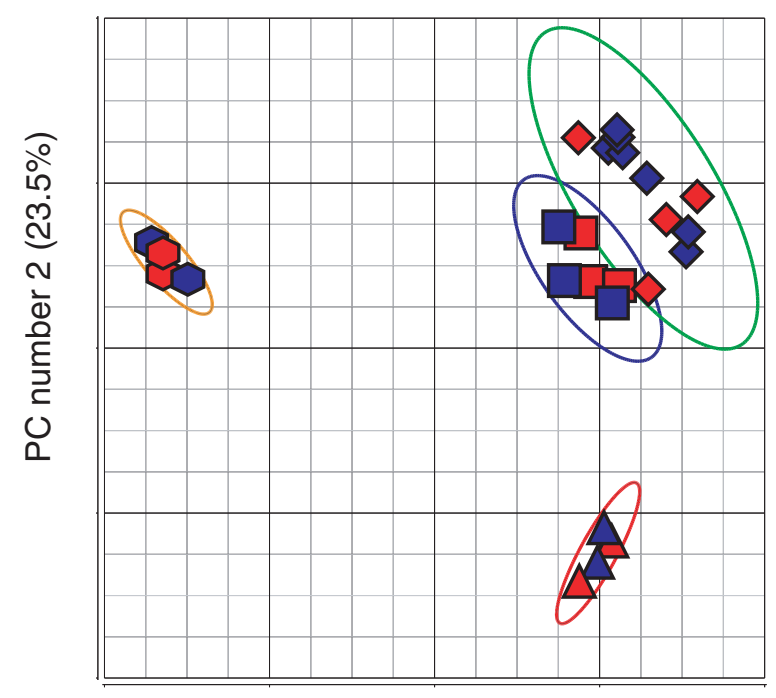

PC number 1 (53.9\%) (b)

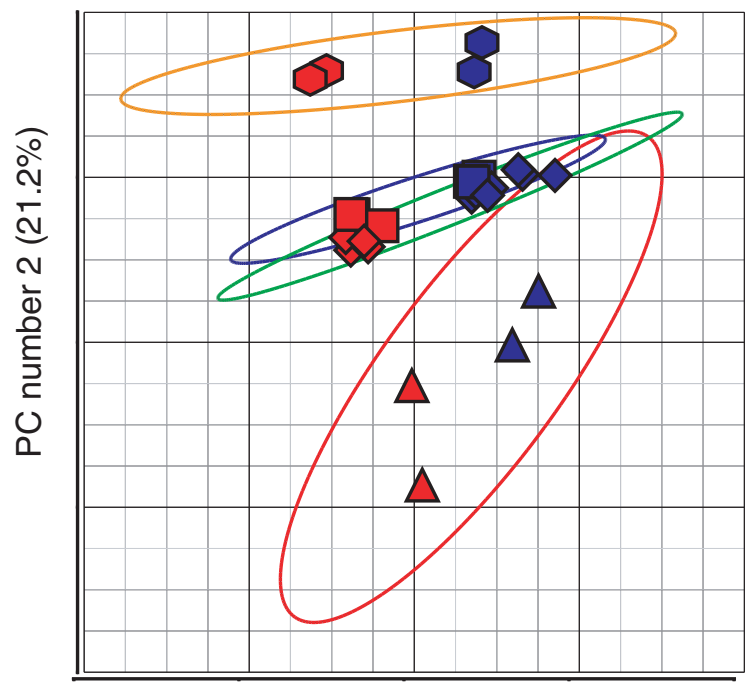

PC number 3 (17.2\%)

(d)

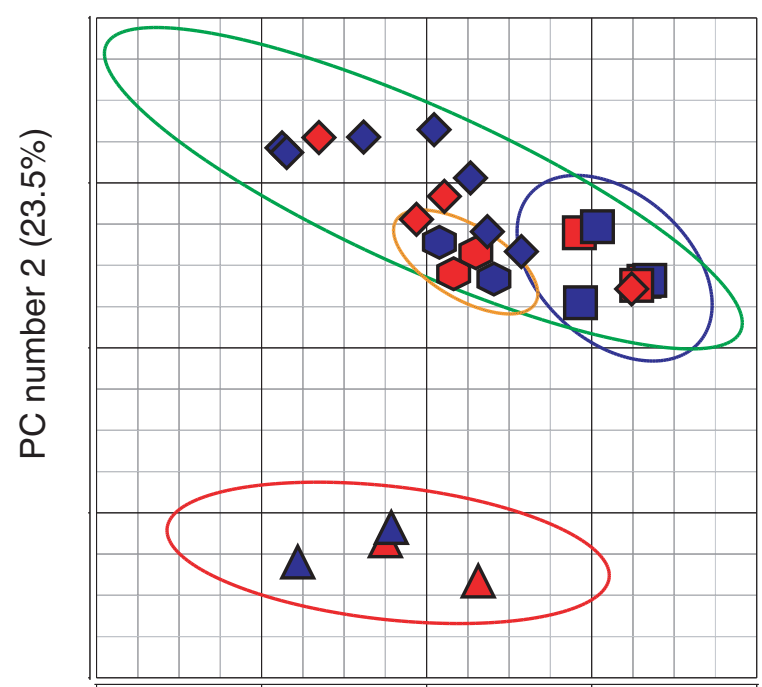

PC number 3 (6.88\%)

Figure I (see legend on next page) 
Figure I (see previous page)

PCA was used to visually assess the major sources of variation in the expression data. For each of the four panels, each data point represents a sample; there are 25 samples total. (a) PCA applied to chromosome $2 \mathrm{I}$ genes. The $x$-axis represents the first PC (accounting for $41 \%$ of the variance) and the $y$ axis represents the second PC (accounting for 21.2\%). The graph is based on expression values for all 253 probe sets assigned to chromosome 21 . This showed that the largest source of variability was due to tissue/cell type, accounting for $62.2 \%$ of the variance in the data. (b) PCA applied to chromosome 21 genes. The $x$-axis corresponds to the third PC, and the $y$-axis corresponds to the second PC. The third PC showed a separation of trisomic from euploid samples based on gene expression, accounting for $17.2 \%$ of the variance in the data. (c) PCA applied to non-chromosome 21 genes. The first two PCs ( $\mathrm{x}$ - and $\mathrm{y}$-axis) using expression values for genes assigned to all other chromosomes also showed that the largest source of variance was due to tissue (77.4\% of total variance). These observations are similar to the results in panel a. (d) PCA applied to non-chromosome 21 genes. The $x$ - and $y$-axis correspond to the third and second PCs, respectively. In contrast to the results of panel b, the third PC failed to show separation of trisomic from euploid samples (6.9\% of total variance). The ellipsoids represent three standard deviations beyond the centroid of each tissue group. Data points correspond to samples (red, Down syndrome; blue, euploid) within a group (cerebrum, diamond symbols on data points, and green ellipsoid; cerebellum, square symbols on data points and blue ellipsoid; astrocyte, triangle symbols on data points and red ellipsoid; heart, hexagon symbols on data points and orange ellipsoid).

complex but limited secondary effects on transcript levels of genes on other chromosomes.

\section{Results \\ Exploratory analyses of gene expression}

We measured the expression levels of up to 18,462 transcripts, representing approximately 15,106 genes, using Affymetrix GeneChip ${ }^{\circledR}$ human U133A microarrays. These transcripts corresponded to 20,261 probe sets, excluding 2,023 Affymetrix bacterial and housekeeping control probes and probes that do not map to any chromosomes. We performed principal components analysis (PCA) to explore the gene expression profiles from four regions (cerebrum, cerebellum, heart, and cerebrum-derived astrocyte cell lines) in human fetal samples diagnosed with TS21 and matched euploid controls (see Additional data file 1). PCA allows the visualization of highly dimensional data along principal component (PC) axes. These axes reflect the degree of variance in the data, allowing the identification of groups of data points having possible biological relevance. For example, two points corresponding to tissue samples that are close together in PCA space are likely to have highly similar overall gene expression profiles. Figure 1 shows the 25 tissue samples mapped from high-dimensional space to three dimensions for exploratory visualization. The first three PCs are displayed on the $\mathrm{x}-$, $\mathrm{y}^{-}$, and $\mathrm{z}$-axes, respectively. The percentage of total variance explained by each PC is displayed on the corresponding axis. This analysis was performed on 253 probe sets (chromosome 21) and 20,008 probe sets (non-chromosome 21) separately. Figure 1 shows that for chromosome 21 and non-chromosome 21 genes, the samples clustered primarily by tissue or cell type. Thus, the largest differences in overall gene expression between the samples exhibited by PCA are attributable to the different tissues or cells. For genes on chromosome 21, TS21 is distinguishable from euploid controls on the third PC, which accounts for $17.2 \%$ of the total variation in 253-dimensional data (Figure 1b). In contrast, PCA mapping of non-chromosome 21 genes (Figure 1c,d) showed no distinction between TS21 and euploid controls. Although only the first three PCs are displayed in Figure 1, a difference between TS21 and euploid controls was not signif- icant on any of the PCs (based on a $t$ test performed on each PC; data not shown).

To further explore the relationships between samples based upon gene expression profiles, we performed hierarchical clustering using average linkage with Euclidean distance (Figure 2). Hierarchical clustering and PCA are 'unsupervised' methods, which do not consider the known sample attributes such as tissue type or disease state when organizing the data. We superimposed the sample information using color coding. Consistent with PCA, cluster analysis indicated that the samples clustered primarily by tissue source in both chromosome 21 genes and non-chromosome 21 genes. The clustering for the chromosome 21 genes showed a tendency to cluster by disease type within the tissue clusters (Figure 2a), whereas no obvious clustering by disease type was evident in the primary clusters or sub-clusters of genes not on chromosome 21 (Figure 2b). Cluster analysis and PCA results are consistent with the hypothesis that TS21 samples are distinguishable from matched euploid samples based upon differences in the expression of genes assigned to chromosome 21. Additionally, these exploratory analyses revealed no substantial outliers or other anomalies in the data.

\section{Statistical testing of gene expression}

We used a mixed-model ANOVA to test the first three hypotheses stated in the introduction. The hypotheses tested included multiple tests on chromosomes or individual genes. Therefore, to protect against false discoveries due to multiple testing, we used the step-up 'false discovery rate' (FDR) [30]. We set the FDR at 0.05 , meaning that the list of significant genes after applying FDR is expected to contain 5\% false positives.

For the first hypothesis, we assessed whether genes assigned to each chromosome displayed overall differential gene expression. Only chromosome 21 showed significant mean overall differential expression between TS21 and euploid controls (Figure 3). Genes on chromosome 21 were expressed at $1.37 \pm 0.02$ fold (mean \pm standard error), while the ratio of TS21/control across the other chromosomes was $1.00 \pm 0.02$ (ranging from $0.96 \pm 0.03$ to $1.02 \pm 0.03$ ). For this first 
Table I

\begin{tabular}{|c|c|c|c|c|c|c|c|c|c|c|c|}
\hline \multirow[t]{2}{*}{ Gene name } & \multirow{2}{*}{$\begin{array}{l}\text { Accession } \\
\text { number }\end{array}$} & \multirow{2}{*}{$\begin{array}{l}\text { Chromosome } \\
\text { number }\end{array}$} & \multirow{2}{*}{$\begin{array}{c}\text { p value } \\
\text { (ANOVA) }\end{array}$} & \multicolumn{2}{|c|}{ Cerebrum } & \multicolumn{2}{|c|}{ Cerebellum } & \multicolumn{2}{|c|}{ Astrocyte } & \multicolumn{2}{|c|}{ Heart } \\
\hline & & & & Control & TS2I & Control & TS2I & Control & TS2I & Control & TS2I \\
\hline $\begin{array}{l}\text { Pituitary tumor-transforming I interacting } \\
\text { protein (PTTG IIP) }\end{array}$ & NM 004339 & 21 & I.50E-07 & 582.6 & 888.1 & 830.9 & 1176.9 & 2355.5 & 3896.0 & 1153.0 & 2003.5 \\
\hline $\begin{array}{l}\text { ATP synthase, } \mathrm{H}+\text { transporting, mitochondrial } \\
\text { FI complex, } \mathrm{O} \text { subunit }(A T P 5 O)\end{array}$ & NM 001697 & 21 & $5.11 \mathrm{E}-07$ & 1509.0 & 2553.5 & 1331.5 & 2327.1 & 1552.9 & 2086.3 & 2375.0 & 4002.1 \\
\hline $\begin{array}{l}\text { SH3 domain binding glutamic acid-rich protein } \\
(\mathrm{SH} 3 \mathrm{BGR})\end{array}$ & NM 007341 & 21 & $7.12 \mathrm{E}-07$ & 20.5 & 44.5 & 21.2 & 48.4 & 38.2 & 130.2 & 606.8 & 1937.5 \\
\hline $\begin{array}{l}\text { ATP synthase, } \mathrm{H}+\text { transporting, mitochondrial } \\
\text { F0 complex, subunit F6 (ATP5) }\end{array}$ & NM 001685 & 21 & $2.47 \mathrm{E}-06$ & 624.4 & 1148.8 & 723.1 & 1013.6 & 881.3 & 1331.5 & 916.4 & 2046.7 \\
\hline $\begin{array}{l}\text { Down syndrome critical region gene } 3 \\
\text { (DSCR3) }\end{array}$ & NM 006052 & 21 & $1.44 \mathrm{E}-05$ & 51.7 & 94.3 & 49.8 & 92.6 & 49.7 & 169.0 & 72.9 & 71.1 \\
\hline $\begin{array}{l}\text { Chromosome } 21 \text { segment HS2ICO48, zinc } \\
\text { finger protein } 294 \text { (ZNF294) }\end{array}$ & NM 015565 & 21 & 3.39E-05 & 165.7 & 283.0 & 161.6 & 228.9 & 78.6 & 127.8 & 107.5 & 178.0 \\
\hline Superoxide dismutase I (SODI) & NM 000454 & 21 & $5.62 \mathrm{E}-05$ & 1176.2 & 2493.4 & 1816.7 & 2860.4 & 2482.7 & 3853.6 & 1789.7 & 3110.8 \\
\hline $\begin{array}{l}\text { ATP synthase, } \mathrm{H}+\text { transporting, mitochondrial } \\
\text { FI complex, } \mathrm{O} \text { subunit (ATP5O) }\end{array}$ & NM 001697 & 21 & $6.94 \mathrm{E}-05$ & 203.7 & 335.9 & 219.1 & 342.7 & 124.5 & 258.4 & 342.4 & 521.4 \\
\hline Cystatin B (stefin B) (CSTB) & NM 000100 & 21 & $7.75 \mathrm{E}-05$ & 412 & 695.0 & 584.6 & 868.9 & 855.1 & 1007.3 & 797.4 & 1034.7 \\
\hline Phosphofructokinase, liver (PFKL) & $\underline{\mathrm{BC} 006422}$ & 21 & $1.93 \mathrm{E}-04$ & 411 & 476.9 & 255.8 & 492.1 & 247.3 & 397.9 & 390.0 & 433.1 \\
\hline $\begin{array}{l}\text { Pyridoxal (pyridoxine, vitamin B6) kinase } \\
\text { (PDXK) }\end{array}$ & NM 003681 & 21 & $2.82 \mathrm{E}-04$ & 50.3 & 137.4 & 70.1 & 149.4 & 118.4 & 261.6 & 96.6 & 139.3 \\
\hline Collagen, type VI, alpha I (COL6AI) & $\underline{\mathrm{AA} 292373}$ & 21 & $5.04 \mathrm{E}-04$ & 559.4 & 963.1 & 1019 & 1417 & 573.7 & 834.4 & 3003.5 & 4177.7 \\
\hline Transmembrane protein I (TMEMI) & $\underline{\mathrm{U} 61500}$ & 21 & $5.25 \mathrm{E}-04$ & 68.4 & 83.6 & 45.0 & 90.8 & 34.5 & 88.5 & 6.6 & 62.8 \\
\hline Ubiquitin specific protease 16 (USP I6) & NM 006447 & 21 & $5.33 \mathrm{E}-04$ & 189.8 & 318.8 & 223.1 & 306.5 & 272.5 & 513.4 & 180.0 & 320 \\
\hline $\begin{array}{l}\text { SMT3 suppressor of mif two } 3 \text { homolog I } \\
\text { (yeast) (SMT3HI) }\end{array}$ & NM 006936 & 21 & $6.27 \mathrm{E}-04$ & 704.0 & 1181.5 & 823.4 & 1233.1 & 698.7 & 1092.9 & 484.6 & 676.5 \\
\hline SON DNA binding protein (SON) & $\times 63071$ & 21 & $7.28 \mathrm{E}-04$ & 701.5 & 975.7 & 807.4 & 870.3 & 781.2 & 1181.3 & 761.7 & 924.7 \\
\hline $\begin{array}{l}\text { Mitochondrial ribosomal protein L39 } \\
\text { (MRPL39) }\end{array}$ & NM 017446 & 21 & $7.48 \mathrm{E}-04$ & 195.2 & 281.5 & 256.7 & 266.2 & 250.6 & 310.1 & 274.1 & 385.9 \\
\hline Interferon gamma receptor 2 (IFNGR2) & NM 005534 & 21 & $8.16 \mathrm{E}-04$ & 553.5 & 754.3 & 507.5 & 692.0 & 881.2 & 1307.9 & 639.5 & 811.15 \\
\hline $\begin{array}{l}\text { Human homolog of ESI (zebrafish) protein } \\
\text { (C2 lorf33) }\end{array}$ & $\underline{D 86062}$ & 21 & $1.02 \mathrm{E}-03$ & 175.5 & 260.5 & 163.5 & 280.1 & 190.0 & 202.1 & 188.4 & 374.7 \\
\hline $\begin{array}{l}\text { Chaperonin containing TCPI, subunit } 8 \\
\text { (theta) (CCT8) }\end{array}$ & NM 006585 & 21 & $1.45 \mathrm{E}-03$ & 1098 & 1520.4 & 743.6 & 956.3 & 619.0 & 1200.8 & 615.1 & 1089.8 \\
\hline $\begin{array}{l}\text { Chromosome } 21 \text { open reading frame } 108 \\
\text { (C2lorfl08) }\end{array}$ & Al803485 & 21 & $1.53 \mathrm{E}-03$ & 52.5 & 101.9 & 61.9 & 91.8 & 60.7 & 105.4 & 25.6 & 71.3 \\
\hline Tryptophan rich basic protein (WRB) & NM 004627 & 21 & $2.18 \mathrm{E}-03$ & 759.6 & 1439.2 & 926.4 & 1182.4 & 728.6 & 1336.5 & 291.9 & 566.5 \\
\hline $\begin{array}{l}\text { SMT3 suppressor of mif two } 3 \text { homolog I } \\
\text { (yeast) (SMT3HI) }\end{array}$ & BG338532 & 21 & $3.15 \mathrm{E}-03$ & 204.0 & 274.6 & 186.6 & 294.2 & 252.2 & 352.2 & 157.3 & 263.7 \\
\hline $\begin{array}{l}\text { HMTI hnRNP methyl-transferase-like I } \\
\text { (HRMTILI) }\end{array}$ & NM 001535 & 21 & $3.62 \mathrm{E}-03$ & 670.0 & 920.5 & 584.2 & 843.2 & 489.1 & 471.6 & 363.0 & 525.2 \\
\hline $\begin{array}{l}\text { Human homolog of ESI (zebrafish) protein } \\
\text { (C2 lorf33) }\end{array}$ & NM 004649 & 21 & $4.00 E-03$ & 491.8 & 818.2 & 589.7 & 918.9 & 455.9 & 665.6 & 713.3 & 1039.4 \\
\hline $\begin{array}{l}\text { Stress } 70 \text { protein chaperone, microsome- } \\
\text { associated, } 60 \mathrm{kDa}(\mathrm{STCH})\end{array}$ & Al718418 & 21 & $4.43 \mathrm{E}-03$ & 276.2 & 477.5 & 289 & 308.5 & 418.2 & 738.6 & 59.0 & 111.4 \\
\hline
\end{tabular}

The average expression values are for the probe sets corresponding to the genes (from MAS5 software). Two genes (ATP5O and C2 Iorf33) each have two probe sets on this list. TS21, trisomy 21.

hypothesis, 23 chromosomes were tested (chromosomes $\mathrm{X}$ and $\mathrm{Y}$ were combined), so the FDR is based on $\mathrm{n}=23$ tests.

For the second hypothesis, we tested whether individual genes assigned to chromosome 21 were differentially expressed in TS21 versus euploid samples. A mixed-model ANOVA (see Materials and methods) identified 26 out of 253 chromosome 21 probe sets (10.2\%) with statistically signifi- cant differential expression at a FDR of 0.05. These most consistently dysregulated genes are listed in Table 1 . For 104 gene expression comparisons listed in Table 1, 103 were increased in TS21 relative to controls. For this hypothesis, the FDR was based on $\mathrm{n}=253$ tests (for the number of probe sets assigned to chromosome 21). 


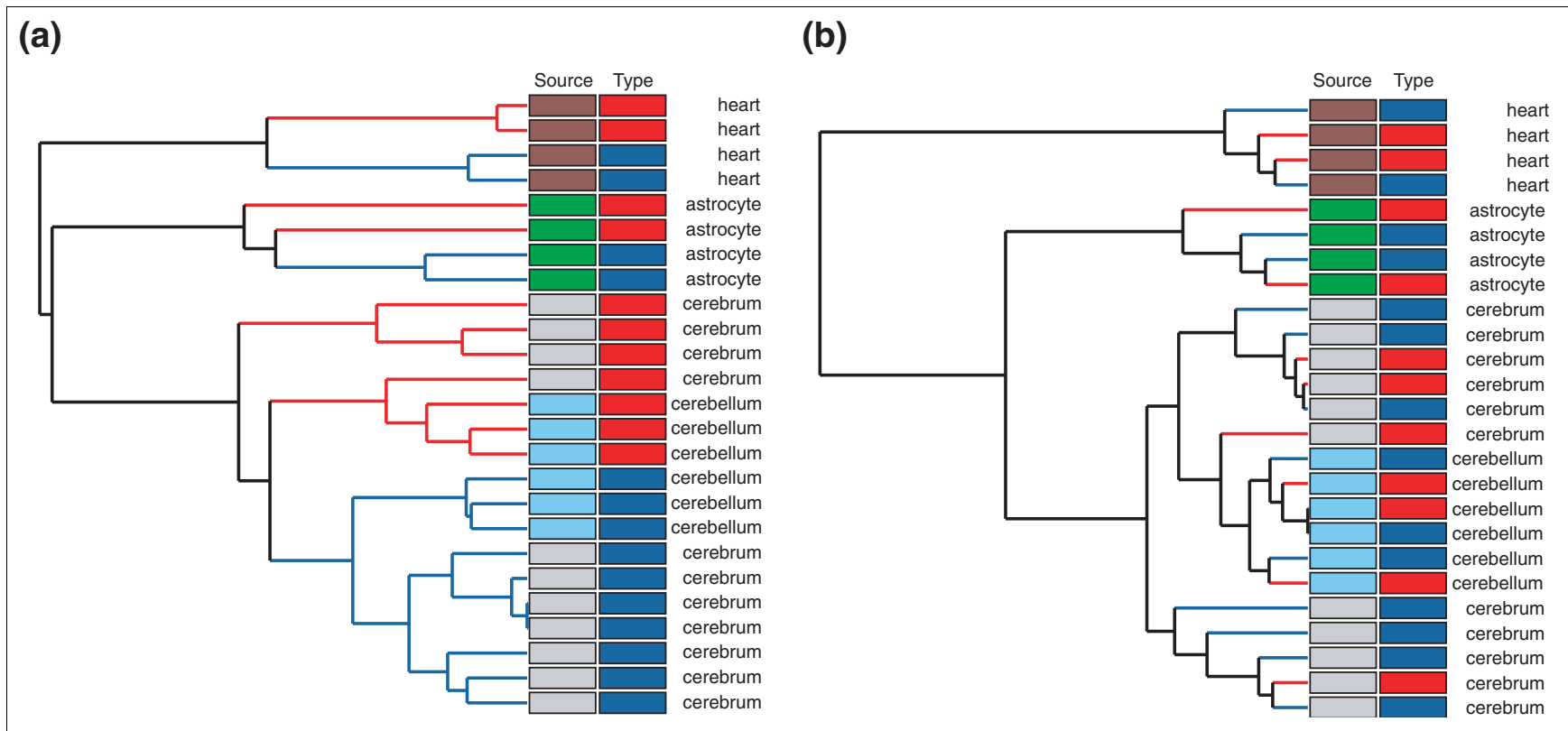

Figure 2

Dendrograms from hierarchical clustering. Dendrograms were based on (a) chromosome $2 I$ genes and (b) non-chromosome 21 genes in the 25 samples, using Euclidean distance and average linkage. Branch lengths represent dissimilarity. Samples were of two types (TS2I, red; euploid, dark blue) and four sources (astrocyte, green; cerebellum, light blue; cerebrum, gray; heart, brown).

For the third hypothesis, we tested whether individual genes not assigned to chromosome 21 were differentially expressed in TS21 relative to euploid samples. The presence of such genes would indicate whether the condition of TS21 causes changes in the transcriptome on chromosomes other than 21, possibly as a secondary consequence of the trisomy. Out of 20,008 non-chromosome 21 probe sets, 14 exhibited statistically significant differential expression at a FDR of 0.05 (Table 2). Using an alternative approach, we performed FDR on each chromosome separately with similar results (Additional data file 2). The same 14 genes passed FDR at the 0.05 level, as well as three additional genes (2,4-dienoyl CoA reductase 1 (NM_o01359) and cholinergic receptor, nicotinic, alpha polypeptide 2 (NM_ooo742), both assigned to chromosome 8, and small inducible cytokine subfamily A (Cys-Cys), member 21 (NM_o02989), assigned to chromosome 9). For chromosome 21 genes, $10.3 \%$ passed FDR at 0.05; for all other chromosomes, the greatest number of genes passing was $0.3 \%$ (chromosome 18) (Additional data file 2).

Based on the mixed-model ANOVA, a large proportion of chromosome 21 genes ( $n=26$ probe sets/253) showed significant altered expression at a FDR of 0.05 , while a very small proportion of non-chromosome 21 genes ( $n=14$ probe sets/ 20,008) were significantly regulated. We further visualized this phenomenon by plotting a histogram of all the $p$ values obtained for chromosome 21 genes $(n=253$; Figure $4 \mathrm{a})$ and for non-chromosome 21 genes $(n=20,008$; Figure $4 \mathrm{~b})$. The histogram in Figure 4a contains 20 bins, at intervals of 0.05 .
If there were no truly differentially regulated genes, each bin would contain $253 \times 0.05=12.65$ transcripts (horizontal line on the figure). The figure indicates that there are many more small $p$ values than expected by chance; there are 62 transcripts with $p<0.05$, while only about 13 would be expected to be less than 0.05 by chance. For non-chromosome 21 genes (Figure $4 \mathrm{~b}$ ), the expected number of genes having a $p$ value less than 0.05 by chance was $1000.4(20,008 \times 0.05)$, whereas the observed number of genes having $p<0.05$ was 1,419. Although there was some tendency for the $p$ values to be smaller than expected by chance, these two histograms provide a visual display of the extent to which the expression of many chromosome 21 genes are significantly different between TS21 and controls, whereas few genes assigned to other chromosomes were significantly regulated.

We asked whether there were regional differences among the significantly regulated genes. For those genes assigned to chromosome 21 (Table 1), the mean ratio of TS21/euploid mRNA level was $1.58 \pm 0.05$ (mean \pm standard error) in the fetal brain tissues and astrocyte cell lines derived from the frontal cortex. Similarly, the TS21/euploid expression ratio in fetal heart was $1.60 \pm 0.09$ (with the exception of TMEM1, for which the TS21/euploid ratio was 9.58). These results are consistent for a gene expression dosage effect caused by trisomy. However, for significantly regulated genes that were not assigned to chromosome 21 (Table 2), a large percent were abundantly expressed and significantly different between TS21 and euploid samples only in the heart, but not 
(a)

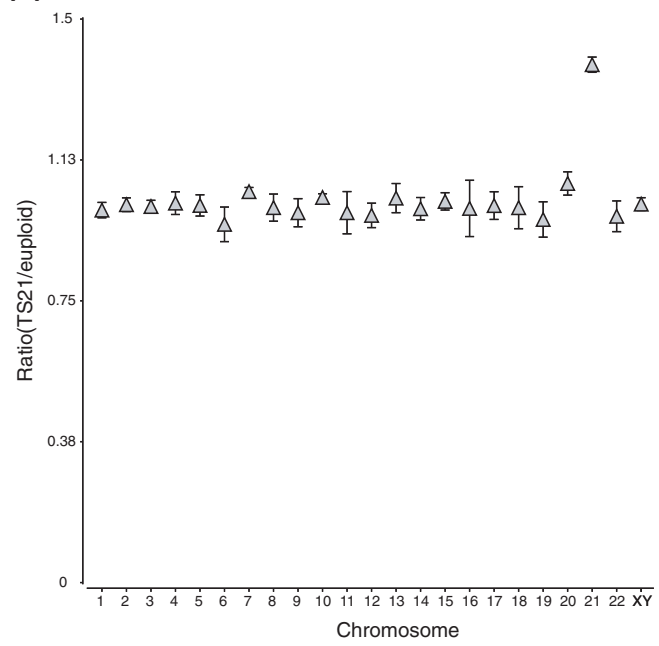

(c)

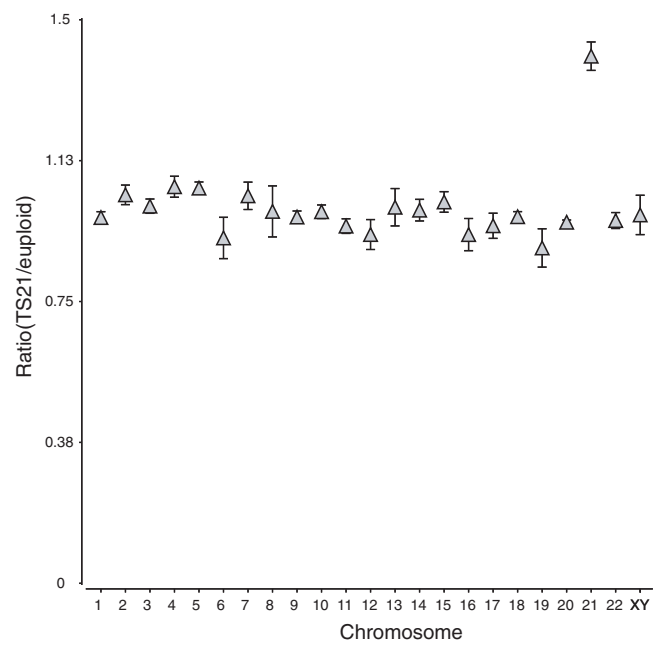

(b)

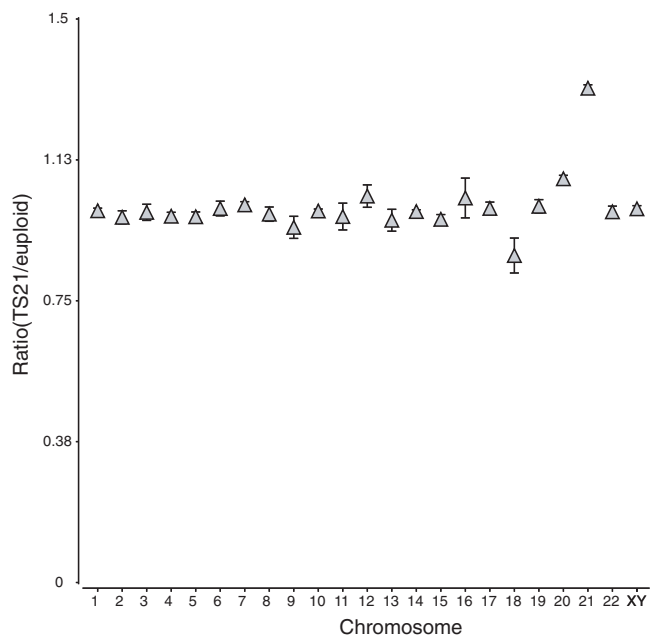

(d)

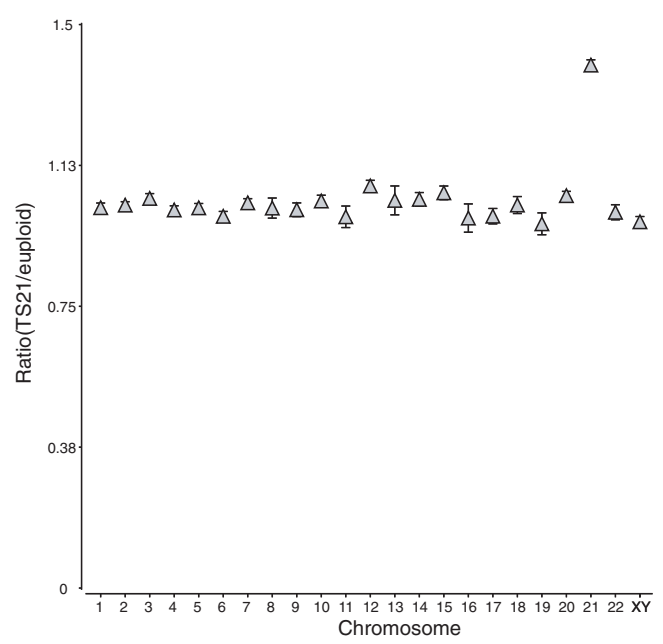

(e)

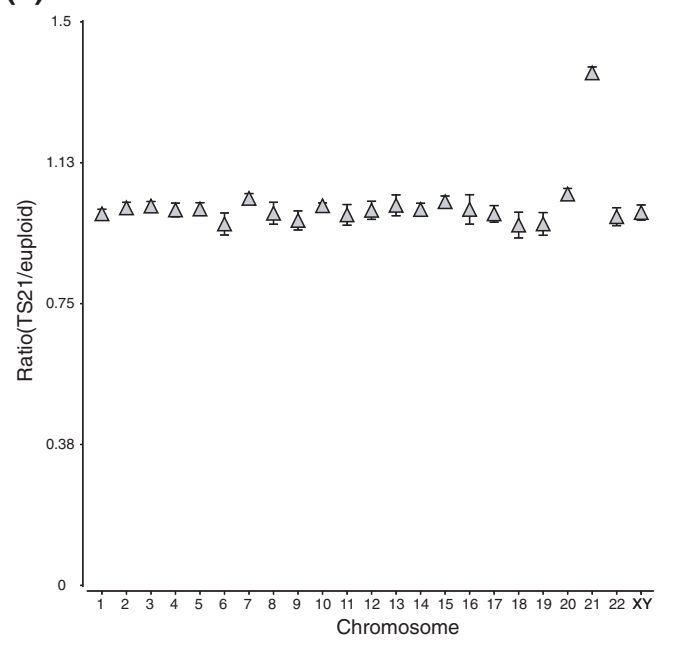

Figure 3 (see legend on next page) 
Figure 3 (see previous page)

Increased transcript levels of genes assigned to chromosome $2 I$ in TS2I samples compared to controls. The plots show ratio (TS2I/euploid) of mean expression values, calculated using data from samples in each tissue or cell type, for all 23 chromosomes. $(X$ and $Y$ chromosome data were pooled.) The expression values were obtained with Affymetrix MAS5 software. The error bars represent standard errors (obtained by performing I,000 iterations of a bootstrap resampling of the tissues). (a) The ratio of TS2I to euploid mean expression values for each chromosome in fetal cerebrum samples. (b) The ratio of TS2I to euploid mean expression values in fetal cerebellum samples. (c) The ratio of TS2I to euploid mean expression values in cultured astrocyte cell lines derived from fetal cerebrum tissues. (d) The ratio of TS2I to euploid mean expression values in fetal heart samples. (e) The ratio of TS2I to euploid mean expression values using data from all the above tissue and cell types.

in the brain. These genes included myomesin 1, myoglobin, calsequestrin 2, cardiac troponin I and T2, and alpha 1 actin.

\section{Classification of TS2I and euploid samples}

To more completely assess differential gene expression, we investigated the ability to classify tissue samples as TS21 or euploid controls using genes on chromosome 21 and genes on chromosomes other than 21. The accuracy estimate for classification using chromosome 21 genes was 99.91\% correct, whereas the estimate for classification using non-chromosome 21 genes was only $48.63 \%$ correct. Tables 3 and 4 show the classification results for the nested cross-validation using chromosome 21 genes and those using non-chromosome 21 genes (see Materials and methods and Additional data file 3 ). As expected, we were able to classify the tissue samples with very high accuracy using chromosome 21 genes (Table 3 ). The classification accuracy when using non-chromosome 21 genes was, however, approximately equal to the accuracy expected by chance (Table 4 ).

\section{Functional group analysis}

Based upon Gene Ontology (GO) annotations [31-33], each of the probe sets represented on the Affymetrix GeneChip ${ }^{\circledR}$ human U133A microarray, having a signal intensity above a background cutoff level, was either assigned to a GO functional group, or else defined as a member of a set excluding that functional group ('non-group members') (see Materials and methods). We asked whether our microarray data might indicate any particular functional groups of genes that were dysregulated in the TS21 samples compared to euploid controls. To address this question, we first performed permutation tests to establish the presence of a signal in the data. Due to the acyclic tree structure of the GO database, with multilevel interconnecting nodes, it is unclear which further permutation test might be performed to optimally define regulated groups. We therefore next applied a $t$ test (or Wilcoxon's rank test for groups with only one or two members) to the gene expression data for two groups of probe sets: each given functional group, and the non-group members. This process was then repeated for all the functional groups. We found 1,141 functional groups for the cerebrum, 1,179 functional groups for the cerebellum, 1,126 functional groups for the astrocyte cell lines, and 1,180 functional groups for the heart.

The first 15 functional groups with the smallest $p$ values for each tissue/cell type are listed in Tables $5,6,7,8$. In particu- lar, the mitochondrion group ( $\mathrm{n}=417$ probe sets) in the fetal cerebrum and heart tissues had the smallest $p$ values from our functional group statistical analyses (Tables 5 and 8). Several other groups related to metabolic pathways, such as oxidoreductase activity ( $\mathrm{n}=299$, in the cerebrum), NADH dehydrogenase activity ( $\mathrm{n}=31$, in the cerebrum and heart), and mitochondrial inner membrane ( $\mathrm{n}=74$, in the heart) were also among the most statistically significantly regulated functional groups (Tables 5 and 8).

To establish that there is signal in the data, we also performed permutation tests. For each functional group, a two sample $t$ test was carried out, testing for a difference in expression for genes associated with this functional group compared to all other observed gene expression levels. If there were no signal in the data, a random assignment of the expression levels (obtained for example by randomly shuffling the observed expression levels) would yield comparable results. However, the distribution of $p$ values obtained from 100 permutation tests (indicated by 100 black lines in the plots) are vastly different from those observed in the original data, indicating that the assumption of no signal in the data was wrong (Additional data files 4 and 5).

For GO functional groups having only one or two genes we applied a Wilcoxon rank test. In each tissue the lowest $p$ value ranged from 0.0006 to 0.0726 for the top 20 GO functional groups having only one member, and 0.0001 to 0.1394 for groups having only two members. After correction for multiple comparisons, none of these values is significant (Additional data file 6), suggesting that none of the GO groups comprising one or two members was significantly regulated in TS21 samples from any tissue.

\section{Confirmation of microarray results}

To confirm the altered expression levels of genes detected by microarrays, we performed over 5,600 quantitative real-time PCRs of cDNA derived from total RNA of the fetal samples. We selected a total of 28 genes from those that had shown the most consistent regulation by ANOVA (Tables 1 and 2), including 18 chromosome 21 genes and 10 non-chromosome 21 genes, based upon their abundance, fold regulation, and $p$ values. We measured their mRNA levels by quantitative realtime PCR in four tissue/cell types, and compared these levels between TS21 and euploid samples. The hypoxanthine phosphoribosyltransferase (HPRT) housekeeping gene was used as a control gene for normalization between samples. Melting 
Table 2

\begin{tabular}{|c|c|c|c|c|c|c|c|c|c|c|c|}
\hline \multirow[t]{2}{*}{ Gene name } & \multirow{2}{*}{$\begin{array}{l}\text { Accession } \\
\text { number }\end{array}$} & \multirow{2}{*}{$\begin{array}{l}\text { Chromoso } \\
\text { me number }\end{array}$} & \multirow{2}{*}{$\begin{array}{l}P \text { value } \\
(\text { ANOVA) }\end{array}$} & \multicolumn{2}{|c|}{ Cerebrum } & \multicolumn{2}{|c|}{ Cerebellum } & \multicolumn{2}{|c|}{ Astrocyte } & \multicolumn{2}{|c|}{ Heart } \\
\hline & & & & Control & TS2I & Control & TS2I & Control & TS2I & Control & TS2I \\
\hline Hypermethylated in cancer I ( $\mathrm{HICl})$ & NM 006497 & 17 & $2.33 \mathrm{E}-08$ & 6.5 & 1.9 & 4.8 & 3.8 & 4.6 & 2.0 & 41.3 & 5.8 \\
\hline Myomesin I (skelemin) (I85 kDa) (MYOMI) & NM 003803 & 18 & $8.82 \mathrm{E}-08$ & 37.8 & 23.3 & 45.0 & 52.6 & 13.6 & 9.8 & 930.1 & 1302.5 \\
\hline Myoglobin (MB) & NM 005368 & 22 & 1.09E-07 & 103.5 & 85.5 & 90.2 & 142.8 & 72.9 & 61.1 & 7392.9 & 12099.8 \\
\hline Calsequestrin 2 (cardiac muscle) (CASQ2) & NM 001232 & 1 & $1.56 \mathrm{E}-07$ & 17.7 & 9.3 & 14.1 & 19.5 & 14.4 & 14.3 & 2341.5 & 3868.7 \\
\hline Ras-related associated with diabetes (RRAD) & NM_004I65 & 16 & $5.06 \mathrm{E}-06$ & 4.5 & 4.2 & 13.3 & 9.8 & 45.8 & 36.6 & 1907.1 & 932.0 \\
\hline Troponin I, cardiac (TNNI3) & NM 000363 & 19 & $5.90 \mathrm{E}-06$ & 49.0 & 44.1 & 44.6 & 71.2 & 31.1 & 25.2 & 2942.4 & 4757.2 \\
\hline $\begin{array}{l}\text { Insulin-like growth factor binding protein } 7 \\
(\text { (IGFBP7) }\end{array}$ & NM 001553 & 4 & I. I2E-05 & 223.8 & $\begin{array}{c}314 . \\
7\end{array}$ & 741.5 & 519.4 & 2418.6 & $\begin{array}{l}4205 \\
.6\end{array}$ & 743.8 & 1137.2 \\
\hline Actin, alpha I, skeletal muscle (ACTAI) & NM 001100 & 1 & $1.20 \mathrm{E}-05$ & 38.6 & 38.5 & 33.7 & 47.6 & 55.9 & $\begin{array}{c}138 . \\
1\end{array}$ & 553.4 & 2310.0 \\
\hline Calcineurin-binding protein calsarcin-I (MYOZ2) & NM 016599 & 4 & $1.22 \mathrm{E}-05$ & 4.9 & 6.3 & 7.6 & 20.2 & 4.7 & 3.0 & 1742.3 & 2592.5 \\
\hline $\begin{array}{l}\text { Teratocarcinoma-derived growth factor I } \\
\text { (TDGFI) }\end{array}$ & NM 003212 & 3 & $1.95 \mathrm{E}-05$ & 10.6 & 11.8 & 8.2 & 9.9 & 31.1 & 20.6 & 11.3 & 187.9 \\
\hline Tenomodulin protein (TNMD) & NM 022144 & $x$ & $2.24 \mathrm{E}-05$ & 7.2 & 5.4 & 10.0 & 6.4 & 5.8 & 4.8 & 23.6 & 103.0 \\
\hline $\begin{array}{l}\text { Olfactory receptor, family } 7 \text {, subfamily E, } \\
\text { member } 12 \text { pseudogene (OR7E I2P) }\end{array}$ & $\underline{\mathrm{AA} 459867}$ & 13 & $2.5 \mathrm{IE}-05$ & 115.4 & 88.7 & 149.1 & 87.6 & 144.8 & $\begin{array}{ll}116 . \\
1\end{array}$ & 215.1 & 58.4 \\
\hline Cardiac troponin T2 (TNNT2) & $\underline{\mathrm{X} 79857}$ & 1 & $2.56 \mathrm{E}-05$ & 47.4 & 39.9 & 47.4 & 45.7 & 44.6 & 32.6 & 3710.3 & 4965.9 \\
\hline $\begin{array}{l}\text { A disintegrin-like and metalloprotease } \\
\text { (reprolysin type) with thrombospondin type I } \\
\text { motif, } 8 \text { (ADAMTSB) }\end{array}$ & NM 007037 & 11 & 3.2IE-05 & 13.0 & 11.5 & 14.6 & 15.5 & 15.1 & 11.4 & 282.8 & 154.7 \\
\hline
\end{tabular}

The average expression values are for the probe sets corresponding to the genes (from MAS5 software). TS2I, trisomy 2 I.

curves and gel electrophoresis of PCR products confirmed the identity of the amplification products (data not shown). The directions of dysregulation and fold changes from real-time PCR results were generally consistent with our microarray findings (Tables 9 and 10). Most genes showed increased transcript levels by both microarray and real-time PCR. Two non-chromosome 21 genes, RRAD and ADAMTS8, were down-regulated in the fetal TS21 heart consistently in microarray and PCR experiments. An example of the results from one real-time PCR experiment for the ZNF 294 gene is shown in Additional data file 7.

All microarray data have been submitted to Gene Expression Omnibus (series accession number GSE1397).

\section{Discussion}

The mechanisms by which an extra copy of chromosome 21 produces the phenotype of DS are complex. Epstein and others have postulated that a triplicated chromosome 21 causes a 50\% increase in the expression of trisomic genes as a primary dosage effect $[5,34]$. This primary effect has been observed in several recent studies. We previously measured the expression levels of approximately 15,000 genes in human fetal cerebrum samples, and in astrocytes derived from cerebrum [16]. We observed that RNA transcripts derived from chromosome 21 genes display a dosage-dependent increase in expression. Other groups have reported simi- lar findings in pooled amniotic fluid cells [8] and in whole blood containing multiple cell types [10]. A primary gene dosage effect has also been observed in several mouse models of DS. Ts65Dn [35] and Ts1Cje [36] mice display learning defects and have segmental trisomy of mouse chromosome 16 , spanning regions that encode orthologs of about one third to one half of the human chromosome 21 genes. A dosagedependent increase in the expression of trisomic genes was reported for Ts1Cje $[11,12]$ and Ts65Dn $[13,14]$ mice relative to euploid controls.

In addition to primary gene dosage effects, secondary (downstream) effects on disomic genes are likely to have a major role in aneuploidies in general and DS in particular $[5,17,37,38]$. However, the nature and extent of such effects in TS21 is controversial [18]. According to one model, trans-acting factors (such as transcription factors) may cause some gene expression changes on chromosomes other than 21, but without a pervasive effect on the transcriptome. Several recent studies support this model. Lyle and colleagues performed quantitative real-time PCR measurements from various tissues of the Ts65Dn mouse, and found changes in the transcript levels of most trisomic genes but zero of 20 disomic genes tested [14]. Similar results were obtained in studies of Ts1Cje mouse brain [11] and cerebellum [12], and in a group of nine tissues in the Ts65Dn mouse [13]. 


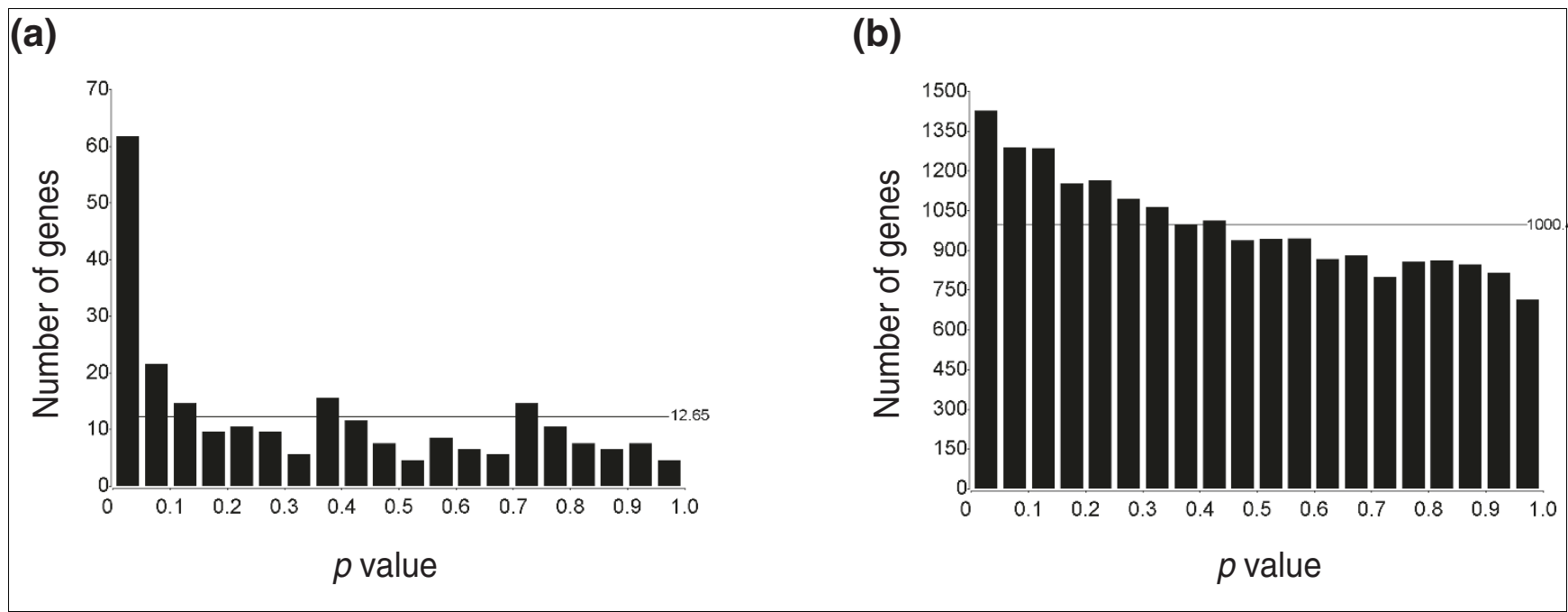

Figure 4

Histograms of $p$ values. (a) Distribution of $p$ values for chromosome 21 genes (253 probe sets represented on the microarray). The histogram contains 20 bins, at intervals of 0.05 . The expected number of genes in each bin by chance alone is $253 \times 0.05=12.65$ (horizontal line). (b) Distribution of $p$ values for non-chromosome 21 genes $(20,008$ probe sets). The expected number of genes having a $p$ value $<0.05$ by random chance is $20,008 \times 0.05=1000.4$ (horizontal line).

\section{Table 3}

Nested cross-validation results using chromosome 21 genes

\begin{tabular}{lcccc}
\hline Pass & Number of samples & Best inner C-V score (\% correct) & Number of tied models & Outer C-V score (\% correct) \\
\hline Subject I & 3 & $100.00 \%(22 / 22)$ & 116 & $100.00 \%$ \\
Subject 2 & 2 & $100.00 \%(23 / 23)$ & 160 & $100.00 \%$ \\
Subject 3 & 4 & $100.00 \%(21 / 21)$ & 119 & $100.00 \%$ \\
Subject 4 & 4 & $100.00 \%(21 / 21)$ & 142 & $99.82 \%$ \\
Subject 5 & 4 & $100.00 \%(21 / 21)$ & 107 & $100.00 \%$ \\
Subject 6 & 1 & $100.00 \%(24 / 24)$ & 131 & $100.00 \%$ \\
Subject 7 & 4 & $100.00 \%(21 / 21)$ & 247 & $99.60 \%$ \\
Subject 8 & 1 & $100.00 \%(24 / 24)$ & 186 & $100.00 \%$ \\
Subject 9 & 1 & $100.00 \%(24 / 24)$ & 107 & $100.00 \%$ \\
Subject 10 & 1 & $100.00 \%(24 / 24)$ & 212 & $100.00 \%$ \\
& & & Accuracy estimate & $99.91 \%$
\end{tabular}

The model space parameters are as follows: Gene selection: ANOVA; Number of genes: I, 3, 5, ..., 25I, 253; Classifier I: K-Nearest Neighbor (KNN); Number of neighbors (K): I, 3, 5; Similarity measures: Euclidean distance, Pearson's correlation, Absolute value (also known as 'City block'); Classifier 2: Nearest Centroid, Prior probability: Equal; Classifier 3: Discriminant Analysis, Discriminant functions: Linear, Quadratic, Prior probability: Equal.

According to a second model, trans-acting factors on chromosome 21 cause a profound disruption of the entire transcriptome. In human cells, FitzPatrick and colleagues [8] reported that genes assigned to chromosome 21 displayed increased transcript levels, but 19 of the 20 most dramatically dysregulated genes did not map to chromosome 21. These results are interpreted as evidence for a mild disomic gene dysregulation [18]. (That study [8] was based on a single initial microarray hybridization. Expression ratios could be measured, but not $p$ values to assess the likelihood that those changes occurred by chance.) Tang et al. [10], studying blood cells from DS versus control cases, reported that 11 of 56 chromosome 21 genes were expressed at increased levels, but across all chromosomes, 191 genes were up-regulated and 433 genes were down-regulated. In the Ts65Dn mouse, Saran et al. [15] measured transcript levels in trisomic and euploid cerebellum, and reported a global destabilization of gene expression, including 922 probes that were significantly, dif- 
Table 4

\begin{tabular}{|c|c|c|c|c|}
\hline Pass & Number of samples & Best inner C-V score (\% correct) & Number of tied models & Outer C-V score (\% correct) \\
\hline Subject I & 3 & $68.18 \%(15 / 22)$ & 12 & $13.89 \%$ \\
\hline Subject 2 & 2 & $69.57 \%(16 / 23)$ & 92 & $1.63 \%$ \\
\hline Subject 3 & 4 & $71.43 \%(15 / 21)$ & 3 & $50.00 \%$ \\
\hline Subject 4 & 4 & $66.67 \%(14 / 21)$ & 3 & $75.00 \%$ \\
\hline Subject 5 & 4 & $76.19 \%(16 / 21)$ & 13 & $25.00 \%$ \\
\hline Subject 6 & I & $75.00 \%(18 / 24)$ & 18 & $0.00 \%$ \\
\hline Subject 7 & 4 & $57.14 \%(12 / 21)$ & 4 & $68.75 \%$ \\
\hline Subject 8 & I & $70.83 \%(17 / 24)$ & 1 & $100.00 \%$ \\
\hline Subject 9 & I & $70.83 \%(17 / 24)$ & 24 & $95.83 \%$ \\
\hline \multirow[t]{2}{*}{ Subject 10} & 1 & $66.67 \%(16 / 24)$ & 1 & $100.00 \%$ \\
\hline & & & Accuracy estimate & $48.63 \%$ \\
\hline
\end{tabular}

The classifier space evaluated was the same as the one used in the chromosome 21 test (Table 3).

Table 5

Most statistically significantly regulated functional groups in the fetal cerebrum tissues based on their $p$ values from $t$ tests

\begin{tabular}{|c|c|c|c|c|c|}
\hline GO group & GO identifier & Number of probe sets & $p$ value & Mean of GO group & $\begin{array}{c}\text { Mean of non-group } \\
\text { members }\end{array}$ \\
\hline Mitochondrion & GO:0005739 & 417 & I.4IE-I4 & 0.03 & 0 \\
\hline $\begin{array}{l}\text { Monovalent inorganic } \\
\text { cation transporter } \\
\text { activity }\end{array}$ & GO:00I5077 & 86 & $3.72 \mathrm{E}-09$ & 0.05 & 0 \\
\hline $\begin{array}{l}\text { Nucleobase, } \\
\text { nucleoside, nucleotide } \\
\text { and nucleic acid } \\
\text { metabolism }\end{array}$ & GO:0006139 & 1495 & $2.00 \mathrm{E}-07$ & -0.02 & 0 \\
\hline Nucleus & GO:0005634 & 2072 & $5.50 \mathrm{E}-07$ & -0.01 & 0 \\
\hline Nucleic acid binding & GO:0003676 & 485 & $1.23 \mathrm{E}-06$ & -0.02 & 0 \\
\hline $\begin{array}{l}\text { Oxidoreductase } \\
\text { activity }\end{array}$ & GO:0016491 & 299 & $3.31 \mathrm{E}-06$ & 0.02 & 0 \\
\hline $\begin{array}{l}\text { NADH dehydrogenase } \\
\text { activity }\end{array}$ & GO:0003954 & 31 & $3.80 \mathrm{E}-06$ & 0.06 & 0 \\
\hline DNA binding & GO:0003677 & 1071 & I.35E-05 & -0.02 & 0 \\
\hline $\begin{array}{l}\text { Cytochrome-c oxidase } \\
\text { activity }\end{array}$ & GO:0004I29 & 25 & $8.51 \mathrm{E}-05$ & 0.05 & 0 \\
\hline RNA binding & GO:0003723 & 466 & I.48E-04 & -0.02 & 0 \\
\hline $\begin{array}{l}\text { Transcription factor } \\
\text { activity }\end{array}$ & GO:0003700 & 558 & $2.40 \mathrm{E}-04$ & -0.02 & 0 \\
\hline Amine metabolism & GO:0009308 & 147 & 3.47E-04 & 0.03 & 0 \\
\hline RNA metabolism & GO:0016070 & 273 & 7.76E-04 & -0.02 & 0 \\
\hline $\begin{array}{l}\text { Heterotrimeric G- } \\
\text { protein GTPase, alpha- } \\
\text { subunit }\end{array}$ & GO:0000263 & 8 & $8.5 I \mathrm{IE}-04$ & 0.04 & 0 \\
\hline Helicase activity & GO:0004386 & 27 & I.I5E-03 & -0.05 & 0 \\
\hline
\end{tabular}

The Gene Ontology (GO) database was used to assign a probe set to a functional group. There were 736 functional groups tested for the cerebrum tissue. The first 12 functional groups with the smallest $p$ values are listed here. The mean of log ratios between trisomy 21 and euploid controls for each functional group was compared to that for the group of remaining probe sets not assigned to that functional group ('non-group members'). After one type of multiple test comparison correction, the cut-off level for statistical significance was $6.79 \mathrm{E}-05$ (assigned by dividing 0.05 by the number of functional groups, 736). 
Table 6

Most statistically significantly regulated functional groups in the fetal cerebellum tissues based on their $p$ values from $t$ tests

\begin{tabular}{|c|c|c|c|c|c|}
\hline GO group & GO identifier & Number of probe sets & $p$ value & Mean of GO group & $\begin{array}{c}\text { Mean of non-group } \\
\text { members }\end{array}$ \\
\hline $\begin{array}{l}\text { Integral to plasma } \\
\text { membrane }\end{array}$ & GO:0005887 & 933 & $1.26 \mathrm{E}-\mathrm{II}$ & 0.03 & 0 \\
\hline RNA binding & GO:0003723 & 469 & $6.3 \mid \mathrm{E}-1 \mathrm{I}$ & -0.02 & 0.01 \\
\hline $\begin{array}{l}\text { Structural constituent } \\
\text { of ribosome }\end{array}$ & GO:0003735 & 212 & I. $12 \mathrm{E}-08$ & -0.03 & 0.01 \\
\hline $\begin{array}{l}\text { G-protein coupled } \\
\text { receptor activity }\end{array}$ & GO:0004930 & 212 & I.29E-08 & 0.06 & 0 \\
\hline $\begin{array}{l}\text { Transmission of nerve } \\
\text { impulse }\end{array}$ & GO:0019226 & 170 & $3.31 \mathrm{IE}-08$ & 0.06 & 0 \\
\hline Nucleus & GO:0005634 & 2194 & $3.55 \mathrm{E}-08$ & -0.01 & 0.01 \\
\hline $\begin{array}{l}\text { Cell surface receptor } \\
\text { linked signal } \\
\text { transduction }\end{array}$ & GO:0007I66 & 592 & $2.24 \mathrm{E}-07$ & 0.03 & 0 \\
\hline Ribosome & GO:0005840 & 147 & $4.68 \mathrm{E}-07$ & -0.03 & 0.01 \\
\hline Defense response & GO:0006952 & 430 & I.07E-06 & 0.04 & 0 \\
\hline $\begin{array}{l}\text { Nucleobase, } \\
\text { nucleoside, nucleotide } \\
\text { and nucleic acid } \\
\text { metabolism }\end{array}$ & GO:0006139 & 1596 & 5.37E-06 & -0.01 & 0.01 \\
\hline Neurogenesis & GO:0007399 & 337 & $9.55 \mathrm{E}-06$ & 0.04 & 0 \\
\hline $\begin{array}{l}\text { Eukaryotic translation } \\
\text { initiation factor } 4 \\
\text { complex }\end{array}$ & GO:0008304 & 13 & $2.5 \mathrm{IE}-05$ & -0.05 & 0.01 \\
\hline RNA metabolism & GO:0016070 & 286 & 4.57E-05 & -0.02 & 0.01 \\
\hline GABA receptor activity & GO:0016917 & 15 & $6.46 \mathrm{E}-05$ & 0.1 & 0.01 \\
\hline DNA binding & GO:0003677 & 1126 & $7.24 \mathrm{E}-05$ & -0.01 & 0.01 \\
\hline
\end{tabular}

There were 764 functional groups tested. The first 12 functional groups with the smallest $p$ values are listed here. The mean of log ratios between TS2I and euploid controls for each functional group was compared to that for the group of remaining probe sets not assigned to that functional group ("non-group members"). After one type of multiple test comparison correction, the cutoff level for statistical significance was $6.54 \mathrm{E}-05$ (assigned by dividing 0.05 by the number of functional groups, 764 ).

ferentially expressed. Even after excluding the 1,532 most regulated probes, they were still able to discriminate trisomic from euploid samples by clustering the remaining gene expression values. This suggests that the expression levels of many thousands of genes are perturbed.

This second model has been supported by other highthroughput approaches. Chrast et al. [39], using serial analysis of gene expression, reported 330 tag differences between Ts65Dn and normal mouse brains, about half of which were significantly over-represented. Only three of the 15 genes for which tags were found from the triplicated region of mouse chromosome 16 were overexpressed, so the majority of dysregulated genes were disomic. In another study, results of differential display PCR analysis on neuronal precursor cells derived from the cerebral cortex of a human TS21 fetus showed that SCG1O and other genes regulated by the REST transcription factor (on chromosome 4) were selectively repressed [40]. We did not observe changes in REST-dependent genes as listed in that study (data not shown).

The present study was motivated in part by an attempt to test these models in human tissues, and in particular in tissues that are pathologically affected in DS (cerebellum and heart). Our results support the first model. We measured the expression of thousands of transcripts in cerebellum, cerebrum, and heart, and combined our analyses with those of a previous study of cerebrum and astrocytes [16]. We observed a primary gene dosage effect using both the descriptive statistics approaches of PCA (Figure 1b) and hierarchical clustering (Figure 2a) and the inferential statistics approach of ANOVA (Figures 3 and $4 \mathrm{a}$ and Table 1). Using these various approaches, we were unable to distinguish trisomic from euploid samples based on the expression levels of genes assigned to chromosomes other than 21 (Figures 1d, 2b, 3 and 4b). Furthermore, classification using nested cross-validation distinguished trisomic from euploid samples based on 
Table 7

The most statistically significantly regulated functional groups in the fetal astrocyte cell lines based on their $p$ values from $t$ tests

\begin{tabular}{|c|c|c|c|c|c|}
\hline GO group & GO identifier & Number of probe sets & $p$ value & Mean of GO group & $\begin{array}{c}\text { Mean of non-group } \\
\text { members }\end{array}$ \\
\hline Collagen & GO:000558I & 15 & 7.76E-07 & 0.33 & -0.01 \\
\hline Endoplasmic reticulum & GO:0005783 & 307 & 8.9IE-07 & 0.03 & -0.02 \\
\hline Fibrillar collagen & GO:0005583 & 14 & $5.01 \mathrm{E}-06$ & 0.29 & -0.01 \\
\hline $\begin{array}{l}\text { Intracellular non- } \\
\text { membrane-bound } \\
\text { organelle }\end{array}$ & GO:0043232 & 122 & $7.94 \mathrm{E}-06$ & -0.06 & -0.01 \\
\hline $\begin{array}{l}\text { G-protein coupled } \\
\text { receptor activity }\end{array}$ & GO:0004930 & $14 \mid$ & $1.26 \mathrm{E}-05$ & -0.09 & -0.01 \\
\hline Gametogenesis & GO:0007276 & 66 & $2.45 \mathrm{E}-05$ & -0.08 & -0.01 \\
\hline $\begin{array}{l}\text { Integral to plasma } \\
\text { membrane }\end{array}$ & GO:0005887 & 734 & 2.57E-05 & -0.04 & -0.01 \\
\hline $\begin{array}{l}\text { Intramolecular } \\
\text { oxidoreductase activity, } \\
\text { interconverting keto- } \\
\text { and enol-groups }\end{array}$ & GO:0016862 & 11 & 2.19E-04 & 0.04 & -0.01 \\
\hline $\begin{array}{l}\text { Carbohydrate } \\
\text { transport }\end{array}$ & GO:0008643 & 16 & $2.40 \mathrm{E}-04$ & 0.1 & -0.01 \\
\hline DNA metabolism & GO:0006259 & 309 & $3.98 \mathrm{E}-04$ & -0.04 & -0.01 \\
\hline $\begin{array}{l}\text { Extracellular matrix } \\
\text { (sensu Metazoa) }\end{array}$ & GO:0005578 & 120 & $6.76 \mathrm{E}-04$ & 0.09 & -0.02 \\
\hline Muscle development & GO:00075I7 & 82 & $6.76 \mathrm{E}-04$ & 0.06 & -0.01 \\
\hline Defense response & GO:0006952 & 381 & 8.5IE-04 & -0.04 & -0.01 \\
\hline Cell adhesion & GO:0007I55 & 227 & 8.9IE-04 & 0.04 & -0.01 \\
\hline $\begin{array}{l}\text { MHC class II receptor } \\
\text { activity }\end{array}$ & GO:00450I2 & 12 & $9.12 \mathrm{E}-04$ & -0.12 & -0.01 \\
\hline
\end{tabular}

There were 734 functional groups tested. The first 12 functional groups with the smallest $p$ values are listed here. The mean of log ratios between trisomy $2 \mathrm{I}$ and euploid controls for each functional group was compared to that for the group of remaining probe sets not assigned to that functional group ('non-group members'). After one type of multiple test comparison correction, the cut-off level for statistical significance was $6.8 \mathrm{IE}$ 05 (assigned by dividing 0.05 by the number of functional groups, 734).

chromosome 21 gene expression with extremely high accuracy, but using non-chromosome 21 genes the accuracy was approximately that expected by chance (Tables 3 and 4). As an approach complementary to microarrays, we carried out a systematic study of transcript levels for 28 individual genes by quantitative real-time PCR. These real-time PCR data confirmed our microarrays findings, and they also represent another independent quantitative measurement of RNA transcript levels in the fetal TS21 brain and heart relative to euploid controls.

The two models do not fully reflect the complexity of the trisomic condition; other factors include dosage compensation, the continuum of secondary effects, and tissue specificity. Dosage compensation is a process by which expression levels of sex chromosome-linked genes are rendered equal in males and females of various eukaryotic species [41,42]. Mechanisms include chromosome inactivation, and hypo- as well as hypertranscription of target genes. Dosage compensation for autosomes has been reported for aneuploid conditions in maize and Drosophila, organisms for which trisomy is less deleterious than in humans $[37,38,43,44]$. Dosage compensation also likely occurs in DS, such that some trisomic chromosome 21 genes are not expressed at elevated levels [5].

In each of the four tissue/cell types we studied, approximately one third of all chromosome 21 genes was expressed, and of these, only a subset of transcripts was expressed at higher levels relative to euploid controls (Figure $4 \mathrm{a}$ and Table 1). Our study included a sufficient sample size to perform ANOVA, as well as quantitative real-time PCR (Table 9), and thus we defined several dozen specific chromosome 21 genes that are dysregulated. Those chromosome 21 genes that were expressed but not regulated may have been subject to dosage compensation. A variety of other human studies, including our previous work [16], lacked sufficient samples and/or microarray replicates to define significantly regulated genes based on a $t$ test or ANOVA with a correction for multiple comparisons $[8,9,19,20]$. 
Table 8

\begin{tabular}{|c|c|c|c|c|c|}
\hline GO group & GO identifier & Number of probe sets & $p$ value & Mean of GO group & $\begin{array}{c}\text { Mean of non-group } \\
\text { members }\end{array}$ \\
\hline Mitochondrion & GO:0005739 & 446 & $6.61 \mathrm{E}-16$ & 0.04 & -0.01 \\
\hline $\begin{array}{l}\text { Monovalent inorganic } \\
\text { cation transporter } \\
\text { activity }\end{array}$ & GO:0015077 & 86 & $4.27 \mathrm{E}-10$ & 0.07 & -0.01 \\
\hline Defense response & GO:0006952 & 485 & $2.29 \mathrm{E}-08$ & -0.06 & -0.01 \\
\hline $\begin{array}{l}\text { NADH dehydrogenase } \\
\text { activity }\end{array}$ & GO:0003954 & 31 & $5.25 \mathrm{E}-06$ & 0.07 & -0.01 \\
\hline Intracellular transport & GO:0046907 & 428 & $2.34 \mathrm{E}-05$ & 0.02 & -0.01 \\
\hline Cell-cell signaling & GO:0007267 & 201 & I.02E-04 & -0.07 & -0.01 \\
\hline $\begin{array}{l}\text { Mitochondrial inner } \\
\text { membrane }\end{array}$ & GO:0005743 & 74 & I.66E-04 & 0.04 & -0.01 \\
\hline $\begin{array}{l}\text { Cell surface receptor } \\
\text { linked signal } \\
\text { transduction }\end{array}$ & GO:0007I66 & 594 & $1.74 \mathrm{E}-04$ & -0.04 & -0.01 \\
\hline $\begin{array}{l}\text { Integral to plasma } \\
\text { membrane }\end{array}$ & GO:0005887 & 948 & $1.95 \mathrm{E}-04$ & -0.03 & -0.01 \\
\hline Extracellular region & GO:0005576 & 215 & $2.40 \mathrm{E}-04$ & -0.06 & -0.01 \\
\hline Membrane fusion & GO:0006944 & 14 & $4.68 \mathrm{E}-04$ & 0.06 & -0.01 \\
\hline DNA metabolism & GO:0006259 & 322 & $8.13 \mathrm{E}-04$ & 0.02 & -0.01 \\
\hline $\begin{array}{l}\text { Regulation of muscle } \\
\text { contraction }\end{array}$ & GO:0006937 & 28 & $9.33 \mathrm{E}-04$ & 0.08 & -0.01 \\
\hline $\begin{array}{l}\text { Single-stranded DNA } \\
\text { binding }\end{array}$ & GO:0003697 & 45 & I.38E-03 & 0.06 & -0.01 \\
\hline Electron carrier activity & GO:0009055 & 12 & I.4IE-03 & 0.08 & -0.01 \\
\hline
\end{tabular}

There were 769 functional groups tested. The first 12 functional groups with the smallest $p$ values are listed here. The mean of log ratios between trisomy $2 \mathrm{I}$ and euploid controls for each functional group was compared to that for the group of remaining probe sets not assigned to that functional group ('non-group members'). After one type of multiple test comparison correction, the cut-off level for statistical significance was 6.50E05 (assigned by dividing 0.05 by the number of functional groups, 769 ).

The secondary effects of TS21 may include either limited or extensive changes to non-chromosome 21 genes, but these alternatives represent extremes of a continuum. Most autosomal aneuploidies are not compatible with life, and each of the most common syndromes (trisomies 13, 18, and 21) likely causes distinct secondary effects based on the particular transcription factors, modifiers of chromatin, or other gene products at dosage imbalance. We identified the significant regulation of at least one transcription factor ( $Z N F 294$; Table 1). The varying results for secondary transcriptional effects reported for human TS21 versus mouse Ts65Dn and Ts1Cje models could, to some extent, reflect differences in the particular transcriptional regulators that are present at dosage imbalance in each system, as well as other factors such as differences in dosage compensation. Another variable is the particular developmental stage being studied, which could have a dramatic effect on both primary and secondary transcriptional effects of trisomy.

The tissue specificity of gene expression in the aneuploid state represents an additional level of complexity. For the four tis- sue and cell types we studied, RNA transcripts from chromosome 21 genes were significantly elevated. However, both of the ANOVA results (Table 2) and real-time PCR assays (Table 10) indicated that there were tissue-specific changes in transcript levels for individual genes on other chromosomes. These include those genes predominantly expressed in the heart but not in the brain, even though the primary genetic insults in all these different tissue or cell types were all an extra copy of chromosome 21. Our analyses on groups of genes that are functionally related also suggested similar region-specific differences in transcription across multiple tissue and cell types (Tables 5, 6, 7, 8). This tissue specificity was also noted in recent mouse models of DS [13,14]. Our study has further significance because we have identified significantly regulated transcripts in affected human tissues. Thus, while template availability results in increased production of RNA transcripts, factors that regulate tissue-specific gene expression have a major role in controlling which specific transcripts are expressed at dosage imbalance. 
Table 9

Quantitative real-time PCR results for selected chromosome $2 \mathrm{I}$ genes in Table I

\begin{tabular}{|c|c|c|c|c|c|c|c|c|c|c|}
\hline \multirow[t]{2}{*}{ Gene name } & \multirow[t]{2}{*}{ Chromosome } & \multirow[t]{2}{*}{$p$ value } & \multicolumn{2}{|c|}{ Cerebrum } & \multicolumn{2}{|c|}{ Cerebellum } & \multicolumn{2}{|c|}{ Astrocyte } & \multicolumn{2}{|c|}{ Heart } \\
\hline & & & Microarray & qPCR & Microarray & qPCR & Microarray & qPCR & Microarray & qPCR \\
\hline $\begin{array}{l}\text { Pituitary tumor-transforming I } \\
\text { interacting protein }(P T T G \| I P)\end{array}$ & 21 & $1.50 \mathrm{E}-07$ & 1.52 & $3.85 \pm 0.38$ & 1.42 & $1.46 \pm 0.62$ & 1.65 & $2.42 \pm 1.16$ & 1.74 & $1.41 \pm 0.16$ \\
\hline $\begin{array}{l}\text { ATP synthase, } \mathrm{H}+\text { transporting, } \\
\text { mitochondrial FI complex, O } \\
\text { subunit (ATP5O) }\end{array}$ & 21 & $5.1 \mathrm{IE}-07$ & 1.69 & $1.52 \pm 0.20$ & 1.75 & $0.91 \pm 0.16$ & 1.34 & $1.48 \pm 0.72$ & 1.69 & $3.52 \pm 1.22$ \\
\hline $\begin{array}{l}\text { ATP synthase, } \mathrm{H}+\text { transporting, } \\
\text { mitochondrial F0 complex, } \\
\text { subunit F6 (ATP5J) }\end{array}$ & 21 & $2.47 \mathrm{E}-06$ & 1.84 & $1.25 \pm 0.14$ & 1.40 & $1.19 \pm 0.12$ & 1.51 & $1.73 \pm 0.78$ & 2.23 & $5.19 \pm 1.60$ \\
\hline $\begin{array}{l}\text { Down syndrome critical region } \\
\text { gene } 3 \text { (DSCR3) }\end{array}$ & 21 & $1.44 \mathrm{E}-05$ & 1.82 & $2.76 \pm 0.44$ & 1.86 & $0.79 \pm 0.38$ & 3.40 & $2.50 \pm 0.62$ & 0.98 & $2.06 \pm 0.06$ \\
\hline $\begin{array}{l}\text { Chromosome } 2 \text { I segment } \\
\text { HS2 I C048, zinc finger protein } \\
294 \text { (ZNF294) }\end{array}$ & 21 & $3.39 \mathrm{E}-05$ & 1.71 & $2.58 \pm 0.24$ & 1.42 & $1.30 \pm 0.42$ & 1.63 & $1.60 \pm 0.24$ & 1.66 & $1.51 \pm 0.14$ \\
\hline Superoxide dismutase I (SODI) & 21 & $5.62 \mathrm{E}-05$ & 2.12 & $1.72 \pm 0.24$ & 1.57 & $1.44 \pm 0.12$ & 1.55 & $2.75 \pm 1.37$ & 1.74 & $2.86 \pm 1.52$ \\
\hline Cystatin B (stefin B) (CSTB) & 21 & $7.75 \mathrm{E}-05$ & 1.69 & $1.21 \pm 0.13$ & 1.49 & $1.21 \pm 0.14$ & 1.18 & $1.92 \pm 0.56$ & 1.30 & $1.88 \pm 0.07$ \\
\hline Phosphofructokinase, liver (PFKL) & 21 & $1.93 \mathrm{E}-04$ & 1.16 & $2.17 \pm 0.14$ & 1.92 & $1.35 \pm 0.08$ & 1.61 & $2.07 \pm 0.44$ & 1.11 & $2.23 \pm 0.55$ \\
\hline $\begin{array}{l}\text { Pyridoxal (pyridoxine, vitamin } \\
\text { B6) kinase (PDXK) }\end{array}$ & 21 & $2.82 \mathrm{E}-04$ & 2.73 & $2.99 \pm 0.40$ & 2.13 & $1.79 \pm 0.20$ & 2.21 & $2.18 \pm 1.01$ & 1.44 & $1.75 \pm 0.09$ \\
\hline $\begin{array}{l}\text { Collagen, type VI, alpha I } \\
\text { (COL6AI) }\end{array}$ & 21 & $5.04 \mathrm{E}-04$ & 1.72 & $3.16 \pm 0.24$ & 1.39 & $0.75 \pm 0.06$ & 1.45 & $2.57 \pm 1.28$ & 1.39 & $1.97 \pm 0.76$ \\
\hline $\begin{array}{l}\text { Ubiquitin specific protease } 16 \\
\text { (USPI6) }\end{array}$ & 21 & $5.33 \mathrm{E}-04$ & 1.80 & $2.75 \pm 0.48$ & 1.30 & $1.33 \pm 0.36$ & 1.67 & $1.70 \pm 0.50$ & 1.67 & $3.40 \pm 1.54$ \\
\hline $\begin{array}{l}\text { SMT3 suppressor of mif two } 3 \\
\text { homolog I (yeast) (SMT3HI) }\end{array}$ & 21 & $6.27 \mathrm{E}-04$ & 1.68 & $1.66 \pm 0.42$ & 1.50 & $0.93 \pm 0.08$ & 1.56 & $2.56 \pm 1.26$ & 1.40 & $4.07 \pm 2.71$ \\
\hline $\begin{array}{l}\text { Mitochondrial ribosomal protein } \\
\text { L39 (MRPL39) }\end{array}$ & 21 & $7.48 \mathrm{E}-04$ & 1.44 & $1.25 \pm 0.08$ & 1.04 & $1.40 \pm 0.27$ & 1.24 & $2.41 \pm 1.14$ & 1.41 & $1.91 \pm 0.29$ \\
\hline $\begin{array}{l}\text { Interferon gamma receptor } 2 \\
\text { (IFNGR2) }\end{array}$ & 21 & 8.16E-04 & 1.36 & $2.21 \pm 0.29$ & 1.36 & $1.78 \pm 0.12$ & 1.48 & $1.82 \pm 0.44$ & 1.27 & $1.27 \pm 0.4 \mathrm{I}$ \\
\hline $\begin{array}{l}\text { Human homolog of ESI } \\
\text { (zebrafish) protein (C2 lorf33) }\end{array}$ & 21 & $1.02 \mathrm{E}-03$ & 1.48 & $5.44 \pm 2.14$ & 1.71 & $1.85 \pm 0.40$ & 1.06 & $1.21 \pm 0.24$ & 1.99 & $1.38 \pm 0.16$ \\
\hline $\begin{array}{l}\text { Chaperonin containing TCPI, } \\
\text { subunit } 8 \text { (theta) (CCT8) }\end{array}$ & 21 & $1.45 \mathrm{E}-03$ & 1.38 & $2.51 \pm 0.44$ & 1.29 & $3.64 \pm 0.92$ & 1.94 & $1.09 \pm 0.07$ & 1.77 & $0.75 \pm 0.04$ \\
\hline $\begin{array}{l}\text { Tryptophan rich basic protein } \\
\text { (WRB) }\end{array}$ & 21 & $2.18 \mathrm{E}-03$ & 1.89 & $5.21 \pm 2.08$ & 1.28 & $1.94 \pm 0.39$ & 1.83 & $2.87 \pm 2.23$ & 1.94 & $1.78 \pm 0.44$ \\
\hline $\begin{array}{l}\text { HMTI hnRNP methyl- } \\
\text { transferase-like I (HRMTILI) }\end{array}$ & 21 & $3.62 \mathrm{E}-03$ & 1.37 & $1.50 \pm 0.54$ & 1.44 & $1.93 \pm 0.36$ & 0.96 & $1.46 \pm 0.50$ & 1.45 & $1.65 \pm 0.05$ \\
\hline
\end{tabular}

Data were normalized to the HPRT housekeeping gene. P values were derived from ANOVA of microarray data. Values for microarray data are foldregulation. For each quantitative PCR ( $(\mathrm{PCR})$ experiment, values were determined by measuring samples in duplicate at multiple concentrations (mean \pm standard error). Each experiment was performed independently at least three times.

Among the significantly regulated genes from ANOVA (Tables 1 and 2), several encode proteins that have roles in mitochondrial function: $A T P_{5} O$ and $A_{5} J$ (two genes encoding subunits of ATP synthase), and mitochondrial ribosomal protein L39 (MRPL39). Their expression levels were increased based on our microarray experiments (Table 1) and subsequent real-time PCR (Table 9). Additionally, various mitochondrion-related functional groups were significantly regulated (see Results and Tables 5 and 8). Abnormal regulation of these transcripts and functional groups could contribute to the impaired mitochondrial function that has been observed in DS [45].

The type VI collagen genes on chromosome 21 have been thought to be involved in the congenital heart defect phenotype in DS $[46,47]$. Consistent with this finding, our microar- ray study indicated that the type VI collagen alpha 1 gene (COL6A1) was one of the most regulated genes (Table 1). Furthermore, six of the non-chromosome 21 genes are associated with cardiac muscle, such as myomesin, myoglobin, and calsequestrin 2 (Table 2). They are all up-regulated (1.34 to 4.17-fold increase) in TS21 fetal heart tissues that consisted of primarily the pulmonary, tricuspid, aortic and mitral valves, ventricular septum, atrial septum, atrioventricular valve, and some surrounding tissues, which are regions in the heart most commonly affected in DS. Among all AVSD cases, 43\% are associated with DS [26]. In particular, the ventricular inlet septum has been reported to be underdeveloped at all stages between 5 and 16 gestational weeks, among other developmental abnormalities [48]. We postulate that the upregulation of genes related to cardiac muscle may be a compensatory response for developmental defects due to tri- 
somy in the DS hearts. For example, in complete AVSD, deficiency of the atrial septum, ventricular septum, and atrioventricular valve result in abnormal communication between the four cardiac chambers, allowing oxygen-rich blood to regurgitate or leak backwards from the left ventricle into the left or right atrium, and back to the lungs again. This causes more work for the heart. With AVSDs, the heart can hypertrophy, as we observed in the TS21 fetal hearts (data not shown). It is possible that the TS21 heart up-regulates muscle-related genes as a secondary effect of the triplication of the entire chromosome 21 or of individual genes. Of 79 genes defined by Barlow et al. [29] as forming a critical region on chromosome 21 for congenital heart disease, seven had increased expression in our study $\mathrm{SH}_{3} B G \mathrm{R}, \mathrm{CSTB}, \mathrm{PFKL}$, $P D X K, T M E M 1$, C21orf33, WRB) (Tables 1 and 9). Although during our dissection we discarded the surrounding muscle tissue wherever it was possible, we cannot eliminate the possibility that our dissection of fetal heart tissue containing predominantly valve and canal regions might have included more muscle tissue in the TS21 cases than in the controls.

\section{Conclusion}

In the present study we report dosage-dependent transcription in human fetal tissues that are pathologically affected in DS. We also identified individual differentially expressed genes based on criteria of statistical significance. For 28 of these genes, we confirmed the regulation by quantitative realtime PCR. The data indicate a primary gene dosage effect in which, in each tissue tested, a group of genes assigned to chromosome 21 were expressed at higher levels relative to euploid controls. Furthermore, while we observed changes in some transcripts derived from non-chromosome 21 genes, our data do not support a model in which there is large-scale disruption of the transcriptome.

Our data indicated that there were tissue- and cell-specific changes of gene expression in TS21 during fetal development. The functional groups indicated by statistical analyses on our microarray data provided initial indications of possible biological pathways affected by TS21. However, the relationship between levels of RNA and the corresponding protein products is at present unknown. As a next step to understand how the changes at the transcript levels lead to DS phenotypes, it is important to analyze the translational machinery by characterization of TS21 protein profiles.

\section{Materials and methods}

\section{Microarray sample dissection and RNA isolation}

All human tissues were obtained from the Brain and Tissue Bank for Developmental Disorders at the University of Maryland with informed consent using Institutional Review Board-approved protocols. Diagnoses, gender, race, and other information is provided in Additional data file 1. Three TS21 and three age- and gender-matched control cerebella were dissected from frozen fetal brains. For the two TS21 and two matched control frozen fetal heart tissues, the regions that contain primarily the pulmonary, tricuspid, aortic and mitral valves, ventricular septum, atrial septum, atrioventricular valve, and some surrounding tissues were dissected. Wherever possible, the peripheral heart muscle tissue was removed to minimize the amount of RNA from muscle tissue. Total RNA was extracted from frozen tissues using RNeasy ${ }^{\circledR}$ Midi Kit (Qiagen, Valencia, CA, USA) according to the manufacturer's instructions. The quantity and purity of RNA were confirmed by spectrophotometry and agarose gel electrophoresis.

\section{Gene expression data acquisition and pre-processing} Gene expression data were obtained using Affymetrix U133A GeneChip ${ }^{\circledR}$ with standard protocols [49] at the Johns Hopkins Microarray Core Facility. Raw data from U133A GeneChips were processed using both Affymetrix Microarray Suite version 5.o (MAS5) software and robust multi-chip analysis (RMA) normalization ( $\mathrm{R}$ version 1.7.1) from BioConductor [50]. The results using either MAS5 (described below) or RMA (data not shown) were very similar, and we did not have a compelling reason to favor one method over the other for this study. In Affymetrix MAS5, signal is calculated using the One-Step Tukey's Biweight Estimate which yields a robust weighted mean. The U133A GeneChip contains a total of 22,284 probes. We removed 2,023 Affymetrix bacterial and housekeeping control probes and probes that do not map to a known chromosomal location. This resulted in 20,261 probes. The data were further subdivided into probes that code for genes assigned to chromosome $21(n=253)$ and probes that code for genes assigned to all other chromosomes ( $\mathrm{n}=$ 20,008) or for each chromosome (Additional data file 2). The Present/Absent description of probes by MAS5 software was not used in our analyses. Data from astrocytes and cerebrum were previously published [16] and were reanalyzed in this study.

\section{Expression data analysis: exploratory analyses}

Exploratory analyses using PCA [51] and hierarchical clustering were performed using Partek ${ }^{\circledR}$ software [52]. All probes (n $=253$ from chromosome 21 and $n=20,008$ from other chromosomes) were used for these analyses. For PCA, we used the covariance dispersion matrix option. The ellipses were drawn at three standard deviations around the centroid of the samples for each of the four tissues (Figure 1). Hierarchical clustering was performed on the 25 tissue samples based on chromosome 21 genes and again based on non-chromosome 21 genes. In each case the Euclidean distance was used, although similar results were achieved using other measures of dissimilarity. Cluster merging was performed using average linkage. The horizontal axes of the dendrograms (Figure 2) correspond to dissimilarity. 
Table 10

\begin{tabular}{|c|c|c|c|c|c|c|c|c|c|c|}
\hline \multirow[t]{2}{*}{ Gene name } & \multirow[t]{2}{*}{ Chromosome } & \multirow[t]{2}{*}{$p$ value } & \multicolumn{2}{|c|}{ Cerebrum } & \multicolumn{2}{|c|}{ Cerebellum } & \multicolumn{2}{|c|}{ Astrocyte } & \multicolumn{2}{|c|}{ Heart } \\
\hline & & & Microarray & qPCR & Microarray & qPCR & Microarray & $\mathrm{qPCR}$ & Microarray & qPCR \\
\hline $\begin{array}{l}\text { Myomesin I (skelemin) (I85 } \\
\text { kDa) (MYOMI) }\end{array}$ & 18 & $8.82 \mathrm{E}-08$ & BBL & - & BBL & - & BBL & - & 1.40 & $1.25 \pm 0.06$ \\
\hline Myoglobin (MB) & 22 & 1.09E-07 & BBL & - & BBL & - & BBL & - & 1.64 & $1.58 \pm 0.16$ \\
\hline $\begin{array}{l}\text { Calsequestrin } 2 \text { (cardiac muscle) } \\
\text { (CASQ2) }\end{array}$ & 1 & $1.56 \mathrm{E}-07$ & BBL & - & BBL & - & BBL & - & 1.65 & $2.89 \pm 0.58$ \\
\hline $\begin{array}{l}\text { Ras-related associated with } \\
\text { diabetes }(R R A D)\end{array}$ & 16 & $5.06 \mathrm{E}-06$ & BBL & - & BBL & - & BBL & - & 0.49 & $0.82 \pm 0.08$ \\
\hline Troponin I, cardiac (TNNI3) & 19 & $5.90 \mathrm{E}-06$ & BBL & - & BBL & - & BBL & - & 1.62 & $1.31 \pm 0.25$ \\
\hline $\begin{array}{l}\text { Insulin-like growth factor binding } \\
\text { protein } 7 \text { (IGFBP7) }\end{array}$ & 4 & $1.12 \mathrm{E}-05$ & 1.41 & $1.02 \pm 0.27$ & 0.70 & $1.55 \pm 0.33$ & 1.74 & $2.12 \pm 0.08$ & 1.53 & $0.77 \pm 0.09$ \\
\hline $\begin{array}{l}\text { Actin, alpha I, skeletal muscle } \\
\text { (ACTAI) }\end{array}$ & 1 & $1.20 \mathrm{E}-05$ & BBL & - & BBL & - & BBL & - & 4.17 & $6.27 \pm 0.59$ \\
\hline $\begin{array}{l}\text { Calcineurin-binding protein } \\
\text { calsarcin-I (MYOZ2) }\end{array}$ & 4 & $1.22 \mathrm{E}-05$ & BBL & - & BBL & - & BBL & - & 1.49 & $1.35 \pm 0.09$ \\
\hline Cardiac troponin T2 (TNNT2) & 1 & $2.56 \mathrm{E}-05$ & BBL & - & BBL & - & BBL & - & 1.34 & $1.31 \pm 0.25$ \\
\hline $\begin{array}{l}\text { A disintegrin-like and } \\
\text { metalloprotease (reprolysin } \\
\text { type) with thrombospondin type } \\
\text { I motif, } 8 \text { (ADAMTS8) }\end{array}$ & 11 & $3.2 \mathrm{IE}-05$ & BBL & - & BBL & - & BBL & - & 0.55 & $0.55 \pm 0.17$ \\
\hline
\end{tabular}

Data were normalized to the HPRT housekeeping gene. $P$ values were derived using the same ANOVA model used for the microarray data. Values for microarray data are fold-regulation. For each QPCR experiment, values were determined by measuring samples in duplicate at multiple concentrations (mean \pm standard error). Each experiment was performed independently at least three times. BBL, below background level; qPCR, quantitative real-time PCR.

\section{Expression data analysis: statistical testing}

A mixed-model ANOVA was used to detect differential expression at individual gene level and at the chromosome level. The ANOVA model was chosen to partition subject-tosubject, tissue, and disease type variability from variability due to biological and experimental noise. ANOVA was performed using Partek ${ }^{\circledR}$ software [52]. The following linear mixed model (equation 1) was used to detect differential expression on a gene-by-gene basis:

$y_{i j k}=D_{i}+T_{j}+D T_{i j}+S(D)_{i k}+\varepsilon_{i j k}$

where $y_{i j k}$ is the expression of the gene for $i$ th disease type, $j$ th tissue, and $k$ th subject. The symbols $D, T, D T$, and $S(D)$ represent effects due to disease, tissue, disease-by-tissue interaction, and subject-nested-within-disease, respectively. The error for each gene for sample $i j k$ is designated as $\varepsilon_{i j k}$. Tissue and disease are fixed effects and subject is a random effect in the mixed model. The average $\mathrm{R}^{2}$ value for genes assigned to chromosome 21 was 0.760 and for all genes assigned to other chromosomes was 0.757 . This indicates that approximately $76 \%$ of the variance in the data was explained by the ANOVA model of equation 1.

To test chromosomes for differential expression, for each of the 25 tissue samples we first averaged all genes from a particular chromosome. For example, a total of 253 expression values (corresponding to 253 probe sets) assigned to chromo- some 21 were averaged. This resulted in 23 values for each tissue sample, with each value representing the average expression of all genes on each chromosome for that tissue sample (chromosome $\mathrm{X}$ and $\mathrm{Y}$ were combined). The linear model of equation 1 was used to test for differential expression between TS21 and euploid controls to test our hypothesis that some chromosomes may show overall differential expression between TS21 and control groups. In each case, the Benjamini-Hochberg step-up FDR [30] was applied to determine the list of genes deemed to be statistically significant.

\section{Expression data analysis: class prediction}

We investigated the ability to classify tissue samples as TS21 or euploid controls based on the expression of genes assigned to chromosome 21, or to other genes. We used Partek ${ }^{\circledR}$ software for these analyses. Detailed methods are available in Additional data file 3 [53]. Briefly, our classification tests employed a nested leave-one-subject-out cross-validation step that was carried out in three parts: gene selection, selection of an optimal classifier, and estimation of classification accuracy. For gene selection (variable selection) we used ANOVA, and varied the number of predictor genes. For selection of an optimal classifier, the methods that we employed were K-Nearest Neighbor [54], Nearest 'Shrunken' Centroid [55], and Discriminant Analysis. For estimation of the classification accuracy, nested cross-validation was performed (see Additional data file 3). The nested cross-validation is per- 
formed using an 'outer' cross-validation that was used to obtain accuracy estimates, and a nested, 'inner' cross-validation that was used to select genes and tune classifier parameters.

\section{Expression data analysis: functional group testing} Most of the probe sets on the Affymetrix GeneChip ${ }^{\circledR}$ human U133A microarray can be assigned to one or more functional groups with a unique ID number based upon GO annotations [31-33]. GO IDs are organized in a tree-like structure via parent-child relationships. The top level has only one group: 'Gene_Ontology', which is then sub-divided into three groups at the second level, including biological_process, cellular_component, and molecular_function. To assess the statistical significance of gene expression differences in distinct functional groups, we implemented a novel $t$ test procedure that we named a $5 \mathrm{~T}$ analysis (tree-travel, transform, $t$ test). This algorithm differs from web-based tools such as GoMiner [56], FatiGO [57], GO:TermFinder [58], or GOTree Machine [59], which define genes as either regulated or not, and employ a Fisher's exact test or hypergeometric distribution analysis. Under the usual assumptions, namely independence and normality of the error, a $t$ test offers more power than a test with a dichotomized outcome. Our algorithm also differs from methods such as MAPPFinder [6o] that assess the significance of a user-defined, predetermined set of genes of interest.

A detailed description of the 5 T method is presented in Additional data file 3 [53]. Briefly, the first step is tree-travel: for each probe set, we parsed its GO annotations, and generated a list of functional groups located in the top six levels of GO tree structure. In the transform step, we generated a list of probe sets assigned to a functional group and a list of probe sets not assigned to this functional group ('non-group members'). In the $t$ test step, for each functional group with three or more members in a tissue/cell type, we performed a $t$ test on this group and non-group members using log ratio gene expression values. The process was repeated for all the functional groups. We then sorted all the functional groups in a tissue/cell type based on their $p$ values from the $t$ tests. To avoid discarding potentially useful information, we also performed Wilcoxon's rank test to assess the statistical significance of differentially regulated functional groups having only one or two members.

We also applied an alternative statistical test to the data based upon a permutation principle. We started with a list of probe sets assigned to a particular functional group. We then randomly selected an equal number of probe sets from all probe sets on the microarray and calculated the mean log ratio values. This random selection was repeated 100 times. The average of the mean log ratio values was calculated, and compared to the mean log ratio value of that particular functional group. The permutation test was performed on all functional groups.

\section{Quantitative real-time PCR}

Total RNA was isolated from frozen tissues or astrocytes using RNeasy ${ }^{\circledR}$ Midi Kit (Qiagen) and followed by cDNA synthesis using Invitrogen SuperScript ${ }^{\mathrm{TM}}$ First-Strand System for RT-PCR (Invitrogen Life Technologies, Carlsbad, CA, USA). Quantitative real-time PCR was performed by a 7900HT Sequence Detector System (Applied Biosystems, Foster City, CA, USA) or LightCycler (Roche Molecular Biochemicals, Indianapolis, IN, USA). Primer sequences are described in Additional data file 8. The expression level of the HPRT housekeeping gene was used for normalization. Detailed methods are provided in Additional data file 3 [53].

\section{Additional data files}

The following additional data are included with the online version of this article. Additional data file 1 is a word document entitled 'Information on samples used in microarray studies'. It lists information on 25 samples such as race, gender, and postmortem interval. Additional data file 2 is a word document entitled 'Results of test for whether individual genes assigned to any chromosome were differentially expressed in TS21 relative to euploid samples'. This table describes FDR results shown for each individual chromosome. Additional data file 3 is a word document entitled 'Additional methods'. This file provides detailed methods for the following topics: Expression data analysis: class prediction; Error estimation using nested cross-validation; Selection of predictor genes for classification; Expression data analysis: functional group testing; and Quantitative realtime PCR. The functional group testing section includes the description of a novel algorithm for functional group analyses. Additional data file 4 is a word document that provides figure legends for the Additional data file 5 and 7 figures. Additional data file 5 is an EPS file entitled 'Permutation test on GO functional groups'. This figure shows the results of permutation tests, providing evidence that the functional groups we identified are likely to have been identified with a probability far greater than is expected by chance (as determined by a series of random permutations of the data). Additional data file 6 is a word document entitled 'Results of Wilcoxon rank test for analysis of functional group regulation'. This table provides results of a Wilcoxon rank test that is appropriate for functional groups having a small size. Additional data file 7 is a tif file entitled 'Relative amounts of ZNF294 transcripts present in the fetal TS21 and euploid cerebrum samples detected by quantitative real-time PCR'. This figure shows a typical quantitative real-time PCR result, in which the level of a transcript is significantly up-regulated in a trisomic sample. Additional data file 8 is a word document entitled 'Primer sequences and other information of the quantitative real-time PCR experiments'. This table includes oligonucleotide sequences. 


\section{Acknowledgements}

The authors thank Ok-Hee Jeon (Johns Hopkins School of Medicine, Baltimore, MD, USA), Mark van der Vlies (Kennedy Krieger Institute, Baltimore, MD, USA), Mary Ann Wilson (Kennedy Krieger Institute, Baltimore, MD, USA), Francisco Martínez Murillo (Johns Hopkins School of Medicine, Baltimore, MD, USA), Rafael Irizarry (Johns Hopkins Bloomberg School of Public Health, Baltimore, MD, USA), and Jing Lin (Partek Incorporated, St Charles, MO, USA) for assistance in generating and analyzing data. We thank H Ronald Zielke (Brain and Tissue Bank, University of Maryland, Baltimore, MD, USA) and Robert Vigorito (Brain and Tissue Bank, University of Maryland, Baltimore, MD, USA) for supplying fetal tissue and cell lines. We thank Scott Zeger (Johns Hopkins School of Public Health, Baltimore, MD, USA) for advice on statistical analyses, and George Capone (Kennedy Krieger Institute, Baltimore, MD, USA), Kirby D Smith (Johns Hopkins School of Medicine, Baltimore, MD, USA), Roger H Reeves (Johns Hopkins School of Medicine, Baltimore, MD, USA), and N Varg for helpful discussions and comments on the manuscript. JK is a Howard Hughes Medical Institute Predoctoral Fellow. IR is supported in part by the NIH grant CA 07484I. JP is supported by R0I HD046598, an MRDDRC grant from the National Institutes of Health, and a grant from the Taishoff Foundation.

\section{References}

I. Kalter H, Warkany J: Congenital malformations (second of two parts). N Engl] Med 1983, 308:49|-497.

2. Hassold T, Hunt PA, Sherman S: Trisomy in humans: incidence, origin and etiology. Curr Opin Genet Dev 1993, 3:398-403.

3. Jackson JF, North ER 3rd, Thomas JG: Clinical diagnosis of Down's syndrome. Clin Genet 1976, 9:483-487.

4. Epstein CJ, Korenberg JR, Anneren G, Antonarakis SE, Ayme S, Courchesne E, Epstein LB, Fowler A, Groner Y, Huret JL, et al:: Protocols to establish genotype-phenotype correlations in Down syndrome. Am J Hum Genet 1991, 49:207-235.

5. Epstein C): The Consequences of Chromosomal Imbalance New York: Cambridge University Press; 1986.

6. Lejeune J, Gautier M, Turpin R: Etudes des chromosomes somatique de neuf enfants mongoliens. Comptes Rendus Academie des Sciences Paris 1959, 248:1721-1722.

7. Jacobs P, Baikie W, Court-Brown W, Strong JA: The somatic chromosomes in mongolism. Lancet 1959, I:710.

8. FitzPatrick DR, Ramsay J, McGill NI, Shade M, Carothers AD, Hastie ND: Transcriptome analysis of human autosomal trisomy. Hum Mol Genet 2002, I I:3249-3256.

9. Giannone S, Strippoli P, Vitale L, Casadei R, Canaider S, Lenzi L, D'Addabbo P, Frabetti F, Facchin F, Farina A, et al.: Gene expression profile analysis in human $T$ lymphocytes from patients with Down Syndrome. Ann Hum Genet 2004, 68:546-554.

10. Tang Y, Schapiro MB, Franz DN, Patterson BJ, Hickey FJ, Schorry EK Hopkin RJ, Wylie M, Narayan T, Glauser TA, et al.: Blood expression profiles for tuberous sclerosis complex 2, neurofibromatosis type I, and Down's syndrome. Ann Neurol 2004, 56:808-814.

II. Amano K, Sago H, Uchikawa C, Suzuki T, Kotliarova SE, Nukina N, Epstein CJ, Yamakawa K: Dosage-dependent over-expression of genes in the trisomic region of $\mathrm{Ts} / \mathrm{Cje}$ mouse model for Down syndrome. Hum Mol Genet 2004, I 3: I333-I340.

12. Dauphinot L, Lyle R, Rivals I, Dang MT, Moldrich RX, Golfier G, Ettwiller L, Toyama K, Rossier J, Personnaz L, et al.: The cerebellar transcriptome during postnatal development of the TsICje mouse, a segmental trisomy model for Down syndrome. Hum Mol Genet 2005, 14:373-384

13. Kahlem P, Sultan M, Herwig R, Steinfath M, Balzereit D, Eppens B, Saran NG, Pletcher MT, South ST, Stetten G, et al.: Transcript level alterations reflect gene dosage effects across multiple tissues in a mouse model of downsyndrome. Genome Res 2004, I4: I 258-1267.

14. Lyle R, Gehrig C, Neergaard-Henrichsen C, Deutsch S, Antonarakis SE: Gene expression from the aneuploid chromosome in a trisomy mouse model of down syndrome. Genome Res 2004, | 4: $1268-1274$

15. Saran NG, Pletcher MT, Natale JE, Cheng Y, Reeves RH: Global disruption of the cerebellar transcriptome in a Down syndrome mouse model. Hum Mol Genet 2003, I 2:2013-2019.

16. Mao R, Zielke CL, Zielke HR, Pevsner J: Global up-regulation of chromosome 21 gene expression in the developing Down syndrome brain. Genomics 2003, 81 1:457-467.
17. Epstein C): Mechanisms of the effects of aneuploidy in mammals. Annu Rev Genet 1988, 22:5I-75.

18. FitzPatrick DR: Transcriptional consequences of autosomal trisomy: primary gene dosage with complex downstream effects. Trends Genet 2005, 2 I:249-253.

19. Chung IH, Lee SH, Lee KW, Park SH, Cha KY, Kim NS, Yoo HS, Kim YS, Lee S: Gene expression analysis of cultured amniotic fluid cell with Down syndrome by DNA microarray. J Korean Med Sci 2005, 20:82-87.

20. Gross SJ, Ferreira JC, Morrow B, Dar P, Funke B, Khabele D, Merkatz I: Gene expression profile of trisomy $2 I$ placentas: a potential approach for designing noninvasive techniques of prenatal diagnosis. Am J Obstet Gynecol 2002, 187:457-462.

21. Davidoff LM: The brain in mongolian idiocy. Arch Neurol Psychiatr 1928, 20:1229-1257.

22. Crome L, Cowie V, Slater E: A statistical note on cerebellar and brain stem weight in mongolism. J Ment Defic Res 1966, 10:69-72.

23. Baxter LL, Moran TH, Richtsmeier JT, Troncoso J, Reeves RH: Discovery and genetic localization of Down syndrome cerebellar phenotypes using the Ts65Dn mouse. Hum Mol Genet 2000, 9:195-202.

24. Tubman TR, Shields MD, Craig BG, Mulholland HC, Nevin NC: Congenital heart disease in Down's syndrome: two year prospective early screening study. $B M]$ |99|, 302: |425-| 427.

25. Freeman SB, Taft LF, Dooley KJ, Allran K, Sherman SL, Hassold TJ, Khoury MJ, Saker DM: Population-based study of congenital heart defects in Down syndrome. Am J Med Genet 1998, 80:213-217.

26. Paladini D, Tartaglione A, Agangi A, Teodoro A, Forleo F, Borghese A, Martinelli P: The association between congenital heart disease and Down syndrome in prenatal life. Ultrasound Obstet Gynecol 2000, 15:104-108.

27. Venugopalan P, Agarwal AK: Spectrum of congenital heart defects associated with Down Syndrome in high consanguineous Omani population. Indian Pediatr 2003, 40:398-403.

28. Fraisse A, Massih TA, Bonnet D, Sidi D, Kachaner J: Cleft of the mitral valve in patients with Down's syndrome. Cardiol Young 2002, | 2:27-3|.

29. Barlow GM, Chen XN, Shi ZY, Lyons GE, Kurnit DM, Celle L, Spinner NB, Zackai E, Pettenati MJ, Van Riper AJ, et al.: Down syndrome congenital heart disease: a narrowed region and a candidate gene. Genet Med 200I, 3:91-10I.

30. Benjamini $Y$, Hochberg $Y$ : Controlling the false discovery rate: apractical and powerful approach to multiple testing. J $R$ Stat Soc 1995, 57:289-300.

3I. Ashburner M, Ball CA, Blake JA, Botstein D, Butler H, Cherry JM, Davis AP, Dolinski K, Dwight SS, Eppig JT, et al:: Gene ontology: tool for the unification of biology. The Gene Ontology Consortium. Nat Genet 2000, 25:25-29.

32. Harris MA, Clark J, Ireland A, Lomax J, Ashburner M, Foulger R, Eilbeck K, Lewis S, Marshall B, Mungall C, et al.: The Gene Ontology (GO) database and informatics resource. Nucleic Acids Res 2004:D258-D26I.

33. Gene Ontology [http://www.geneontology.org]

34. Epstein CJ: Down syndrome (Trisomy 21). In The Metabolic and Molecular Bases of Inherited Disease Volume I. 8th edition. Edited by: Scriver CR, Beaudet AL, Sly WS, Valle D. New York: McGraw-Hill; 200I:I223-I256.

35. Reeves RH, Irving NG, Moran TH, Wohn A, Kitt C, Sisodia SS, Schmidt C, Bronson RT, Davisson MT: A mouse model for Down syndrome exhibits learning and behaviour deficits. Nat Genet 1995, I I:I77-I84.

36. Sago H, Carlson EJ, Smith DJ, Kilbridge J, Rubin EM, Mobley WC, Epstein CJ, Huang TT: TsICje, a partial trisomy 16 mouse model for Down syndrome, exhibits learning and behavioral abnormalities. Proc Natl Acad Sci USA 1998, 95:6256-626I.

37. Birchler JA, Bhadra U, Bhadra MP, Auger DL: Dosage-dependant gene regulation in multicellular eukaryotes: implications for dosage compensation, aneuploid syndromes, and quantitative traits. Dev Biol 200I, 234:275-288.

38. Birchler JA, Riddle NC, Auger DL, Veitia RA: Dosage balance in gene regulation: biological implications. Trends Genet 2005, 21:219-226.

39. Chrast R, Scott HS, Papasavvas MP, Rossier C, Antonarakis ES, Barras C, Davisson MT, Schmidt C, Estivill X, Dierssen M, et al.: The mouse brain transcriptome by SAGE: differences in gene expres- 
sion between P30 brains of the partial trisomy 16 mouse model of Down syndrome (Ts65Dn) and normals. Genome Res 2000, 10:2006-2021.

40. Bahn S, Mimmack M, Ryan M, Caldwell MA, Jauniaux E, Starkey M, Svendsen CN, Emson P: Neuronal target genes of the neuronrestrictive silencer factor in neurospheres derived from fetuses with Down's syndrome: a gene expression study. Lancet 2002, 359:310-315.

4I. Marin I, Siegal ML, Baker BS: The evolution of dosage-compensation mechanisms. Bioessays 2000, 22: I I06-III4.

42. Pannuti A, Lucchesi JC: Recycling to remodel: evolution of dosage-compensation complexes. Curr Opin Genet Dev 2000, 10:644-650.

43. Devlin RH, Holm DG, Grigliatti TA: The influence of whole-arm trisomy on gene expression in Drosophila. Genetics 1988, II 8:87-10I.

44. Guo M, Davis D, Birchler JA: Dosage effects on gene expression in a maize ploidy series. Genetics 1996, 142: I349-1355.

45. Busciglio J, Pelsman A, Wong C, Pigino G, Yuan M, Mori H, Yankner BA: Altered metabolism of the amyloid beta precursor protein is associated with mitochondrial dysfunction in Down's syndrome. Neuron 2002, 33:677-688.

46. Kitten GT, Kolker SJ, Krob SL, Klewer SE: Type VI collagen in the cardiac valves and connective tissue septa during heart development. Braz J Med Biol Res 1996, 29: I I89-I I 93.

47. Klewer SE, Krob SL, Kolker SJ, Kitten GT: Expression of type VI collagen in the developing mouse heart. Dev Dyn 1998, 2II:248-255.

48. Blom NA, Ottenkamp J, Wenink AG, Gittenberger-de Groot AC: Deficiency of the vestibular spine in atrioventricular septal defects in human fetuses with down syndrome. Am J Cardiol 2003, $91: 180-184$.

49. Affymetrix [http://www.affymetrix.com]

50. BioConductor [http://www.bioconductor.org]

5I. Jackson JE: A User's Guide to Principal Components New York: WileyInterscience; 1991.

52. Partek, Inc. [http://www.partek.com]

53. The Pevsner Laboratory [http://pevsnerlab.kennedykrieger.org/ index_ds.htm]

54. Dasarathy BV: Nearest Neighbor (NN) Norms: NN Pattern Classification Techniques Los Alamitos, CA: IEEE Computer Society Press; 1991.

55. Tibshirani R, Hastie T, Narasimhan B, Chu G: Diagnosis of multiple cancer types by shrunken centroids of gene expression. Proc Natl Acad Sci USA 2002, 99:6567-6572.

56. Zeeberg BR, Feng W, Wang G, Wang MD, Fojo AT, Sunshine M, Narasimhan S, Kane DW, Reinhold WC, Lababidi S, et al:: GoMiner: a resource for biological interpretation of genomic and proteomic data. Genome Biol 2003, 4:R28.

57. Al-Shahrour F, Diaz-Uriarte R, Dopazo J: FatiGO: a web tool for finding significant associations of Gene Ontology terms with groups of genes. Bioinformatics 2004, 20:578-580.

58. Boyle El, Weng S, Gollub J, Jin H, Botstein D, Cherry JM, Sherlock G: GO:TermFinder - open source software for accessing Gene Ontology information and finding significantly enriched Gene Ontology terms associated with a list of genes. Bioinformatics 2004, 20:37I0-37I5.

59. Zhang B, Schmoyer D, Kirov S, Snoddy J: GOTree Machine (GOTM): a web-based platform for interpreting sets of interesting genes using Gene Ontology hierarchies. BMC Bioinformatics 2004, 5: 16.

60. Doniger SW, Salomonis N, Dahlquist KD, Vranizan K, Lawlor SC, Conklin BR: MAPPFinder: using Gene Ontology and GenMAPP to create a global gene-expression profile from microarray data. Genome Biol 2003, 4:R7. 